\title{
Guide for Labeling Consumer Package by Weight, Volume, Count, or Measure (length, area or thickness)
}

\author{
Editors: \\ David Sefcik \\ Lisa Warfield
}

This publication is available free of charge from:

https://doi.org/10.6028/NIST.SP.1020

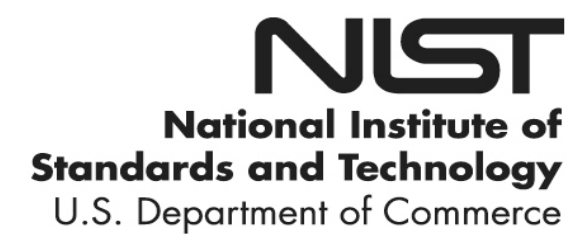




\title{
Guide for Labeling Consumer Package by Weight, Volume, Count, or Measure (length, area or thickness)
}

\author{
Editors:
}

David Sefcik

Lisa Warfield

Dr. Douglas Olson, Chief Office of Weights and Measures Physical Measurement Laboratory

This publication is available free of charge from:

https://doi.org/10.6028/NIST.SP.1020

June 2020

NIST SP 1020 supersedes all previous editions

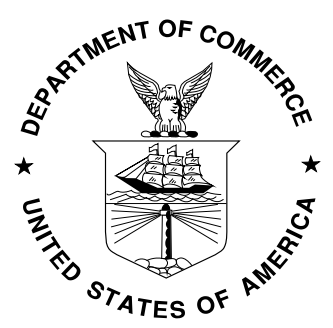

U.S. Department of Commerce Wilbur L. Ross, Jr., Secretary

National Institute of Standards and Technology Walter Copan, NIST Director and Undersecretary of Commerce for Standards and Technology 
Certain commercial entities, equipment, or materials may be identified in this document in order to describe an experimental procedure or concept adequately. Such identification is not intended to imply recommendation or endorsement by the National Institute of Standards and Technology, nor is it intended to imply that the entities, materials, or equipment are necessarily the best available for the purpose.

National Institute of Standards and Technology Special Publication 1020

Natl. Inst. Stand. Technol. Spec. Publ. 1020, 40 pages (June 2020)

This publication is available free of charge from: https://doi.org/10.6028/NIST.SP.1020 


\section{Foreword}

This document, "Guide for Labeling Consumer Packages by Weight, Volume, Count, or Measure (length, area, or thickness)," is based on the Uniform Packaging and Labeling Regulation (UPLR) in National Institute of Standards and Technology Handbook 130, "Uniform Laws and Regulation in the Areas of Legal Metrology and Fuel Quality." It provides a summary of labeling requirements for consumer products and commodities sold by weight, volume, count, or measure. This guide is not a replacement for the UPLR. The reader should refer to the UPLR to ensure that all requirements are met. This guide does not apply to wine, malted beverages and distilled spirits, some packages of meat and poultry products subject to the label requirements of the U.S. Department of Agriculture, and to packages labeled for export.

The superseded documents are:

NIST SP 1020-1 "Consumer Package Labeling Guide: Selling by Weight” (August 2005)

NIST SP 1020-2 "Consumer Package Labeling Guide: Selling by Volume" (August 2005)

NIST SP 1020-3 "Consumer Package Labeling Guide: Selling by Count" (December 2005)

NIST SP 1020-4 "Consumer Package Labeling Guide: Selling by Length and Area" (May 2006)

You are invited to provide online feedback regarding this document at: www.surveymonkey.com/s/customer-satisfaction-pub or by e-mail to: owm@nist.gov. 
THIS PAGE INTENTIONALLY LEFT BLANK 


\section{Table of Contents}

Part 1. Introduction

Part 2. Label Requirements for Consumer Packages.....................................................................................................

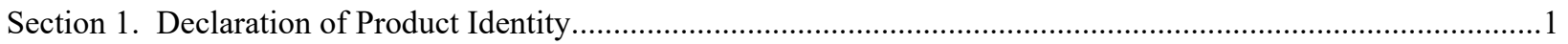

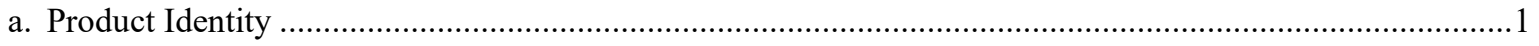

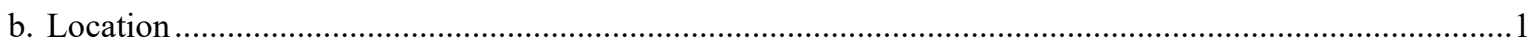



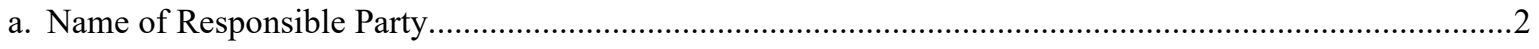

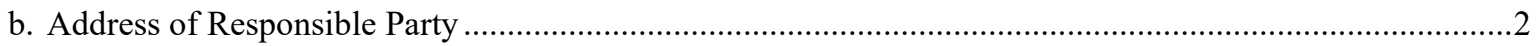

Section 3. Declaration of Net Quantity of Contents ....................................................................................

a. Units of Measure - Use of SI (Metric System) and U.S. Customary Units - Order of Presentation.............3

b. The Accuracy of Net Quantity Declarations and Package Requirements..................................................

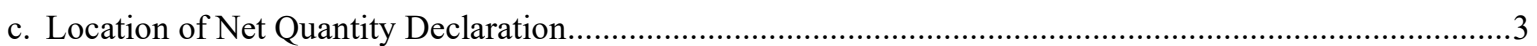

d. Determine the Minimum Type Size Required for the Net Quantity of Contents Declaration ...................... 3

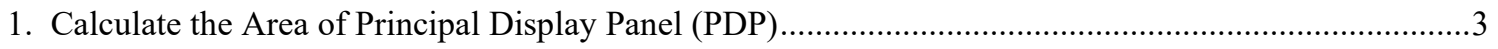

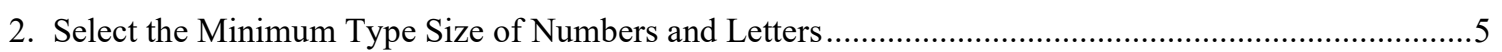

3. Measuring the Type Size of Numbers and Letters................................................................... 6

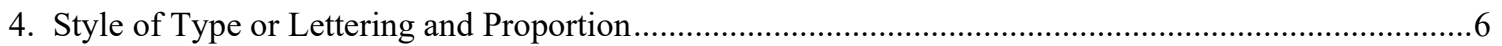

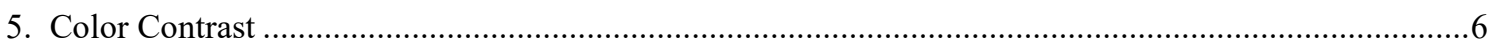

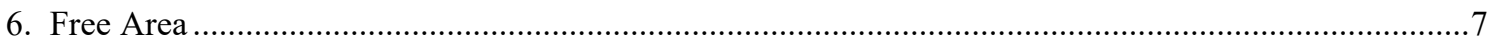

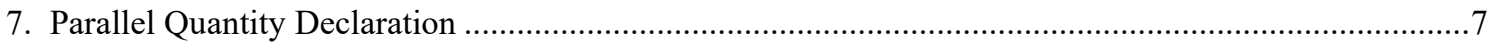

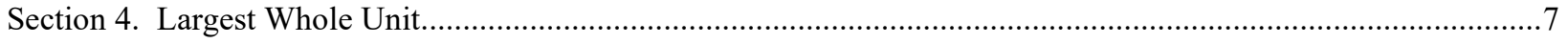

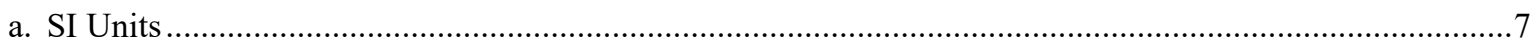

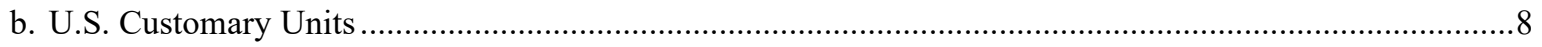

Section 5. Qualification of a Quantity Declaration is Prohibited.....................................................................

Section 6. Combination Declarations of Net Quantity of Contents ................................................................

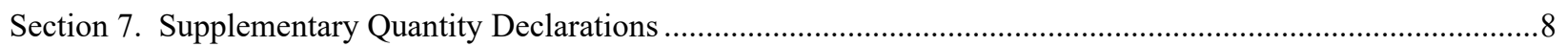

Section 8. Terms Permitted to be Shown with a Net Quantity Declaration......................................................

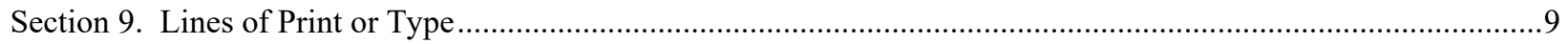

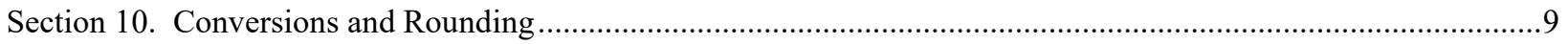

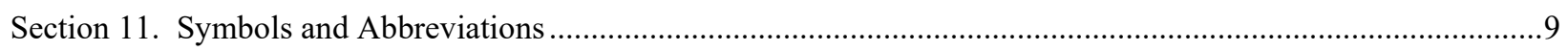

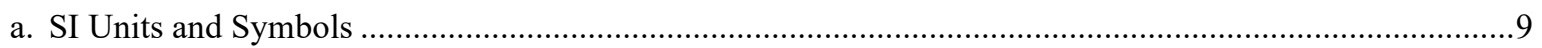

b. Abbreviations for U.S. Customary Units and Other Terms ................................................................ 10

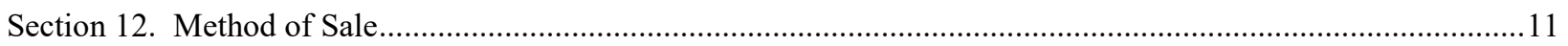

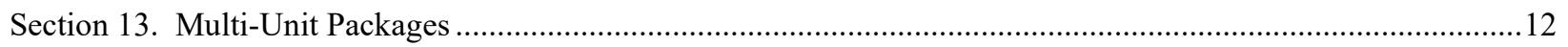

a. Individual Packages Labeled for Individual Retail Sale in a Multi-Unit Package ................................12

b. Individual Packages Not Labeled for Individual Retail Sale in a Multi-Unit Package .............................12

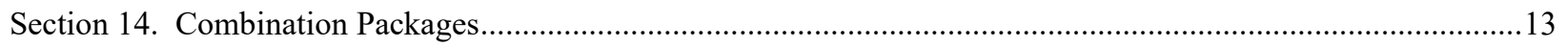




Part 3. Packages Labeled by Weight (mass)..............................................................................................................14





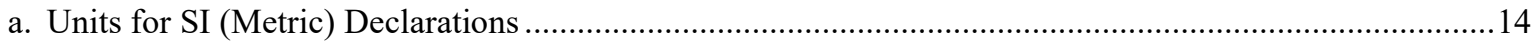

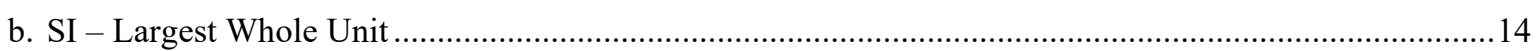

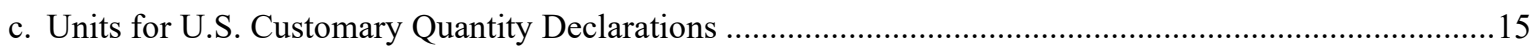

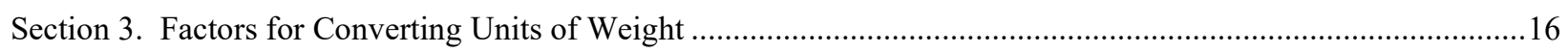

Part 4. Packages Labeled by Volume.....................................................................................................................

Section 1. Words Accompanying a Quantity Declaration ........................................................................................18

Section 2. Product Reference Temperatures................................................................................................

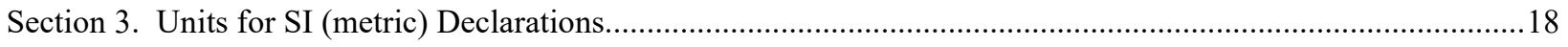

Section 4. Requirements for Quantity Declarations in U.S. Customary Units .........................................................19

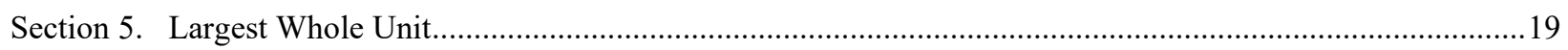

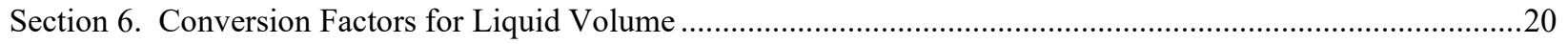

Section 7. Factors for Converting the Volume of Dry Measure ……...................................................................22

Part 5. Packages Labeled by Measure (Length, Area, Thickness) ................................................................................23

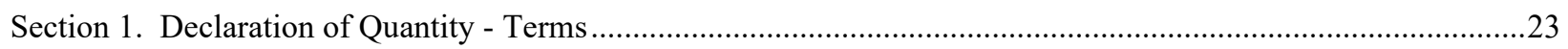

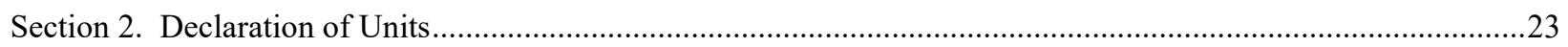

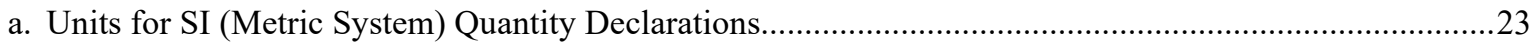

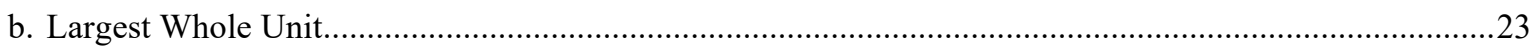

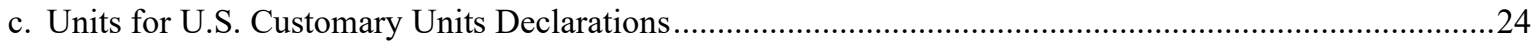

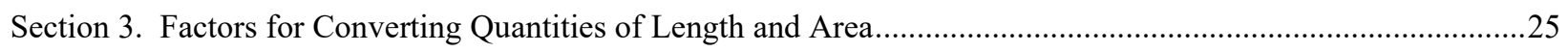

Part 6. Packages Labeled by Count ……………….................................................................................................................27

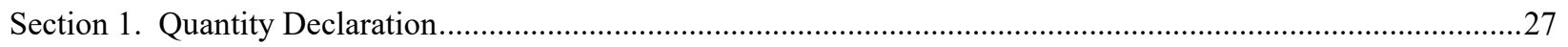

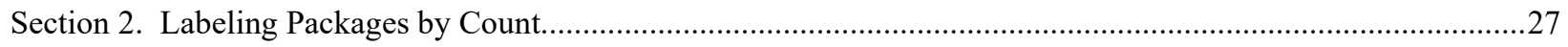

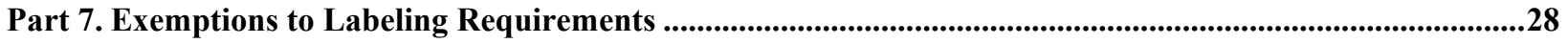

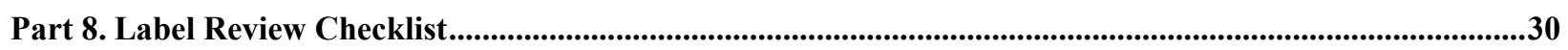

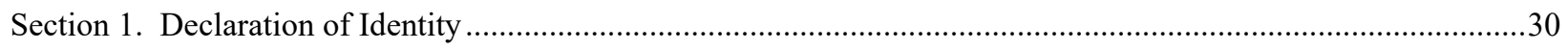

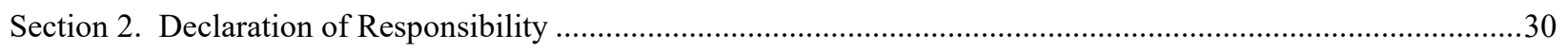

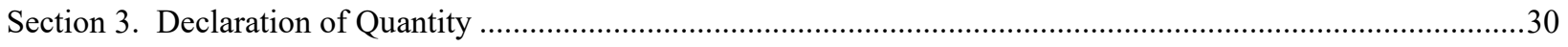

Part 9. Resources ..........................................................................................................................................................31

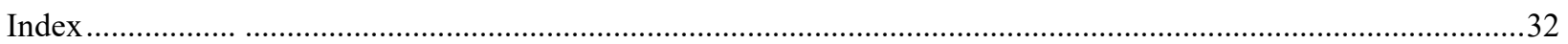




\section{Part 1. Introduction}

This guide provides an overview of the requirements for labeling packaged goods to be offered for sale by weight, volume, count, and measure (or combinations of these quantities). It is based on the Uniform Packaging and Labeling Regulation (UPLR) in National Institute of Standards and Technology (NIST) Handbook 130, "Uniform Laws and Regulation in the Areas of Legal Metrology and Fuel Quality" at www.nist.gov/pml/weights-andmeasures/publications/nist-handbooks/handbook-130. The UPLR requires manufacturers and packers to provide declarations of identity and net quantity of contents on their packages so consumers can make value comparisons based on price and quantity. The UPLR is used as the model for the labeling regulations in most States. For a State by State compilation, see Section II. "Uniformity of Laws and Regulations" (UPLR) in NIST Handbook 130.

The UPLR is consistent with the Fair Packaging and Labeling Act (FPLA) and regulations issued by the Federal Trade Commission (FTC), Food and Drug Administration (FDA), Environmental Protection Agency (EPA), and U.S. Department of Agriculture (USDA) - Food Safety and Inspection Service (FSIS). This guide should be used with the latest edition of NIST Handbook 130, UPLR. If information in this guide conflicts with the UPLR, the UPLR requirement supersedes this guide. The guide only provides information on legal metrology requirements, so the user must determine if other labeling requirements apply (e.g. nutritional and ingredient information; Country of Origin Labeling (COOL); warning labels and safe-use instructions for hazardous products).

\section{Part 2. Label Requirements for Consumer Packages}

This section describes the general labeling requirements for all packaged goods sold by weight, volume, count or measure (e.g., length, width, and thickness). Additional guidance on other requirements, conversion factors, and information is presented in later sections. Specific requirements for quantity declarations are found in Part III. "Packages Labeled by Weight (Mass)," Part IV. "Packages Labeled by Volume," Part V. "Packages Labeled by Measure (length, area and thickness)", and Part VI. "Packages Labeled by Count." A list of exemptions is included in Part VII. "Exemptions to Labeling Requirements." The following declarations are required to appear on packaged goods:

- product identity;

- responsibility; and

- net quantity of contents.

All required information must appear on a consumer package in the English. The information presented shall be prominent, definite, plain, and conspicuous as to the size, style of letters, numbers, and to the color of letters and numbers, in color contrast with its background. The required information may appear in other languages (e.g., Spanish, French or both) as long as it is also shown in English.

\section{Section 1. Declaration of Product Identity}

The following explain the product identity requirement and where the identity must appear on the package.

\section{a. Product Identity}

Shall be given in terms of the name specified in or required by any applicable law or regulation or, in the absence of this the common or usual name or, in the absence of this, the generic name or other appropriate description, including a statement of function (e.g., "cleaning powder"). The product identity shall not be misleading or deceptive.

\section{b. Location}

The declaration of identity shall appear on the Principal Display Panel (PDP). The PDP is defined as that part, or those parts, of a label that is, or are, so designed as to most likely be displayed, presented, shown, or examined under normal and customary conditions of display and purchase (see Figure 1. "Declaration of Identity on a Principal Display Panel"). It is the manufacturer or packer who determines the PDP. If a PDP panel appears 
more than once on a package the requirements apply to all other PDP panels. The product identity shall appear generally parallel to the base on which the package was designed to rest during retail display as determined by the manufacturer or packer.

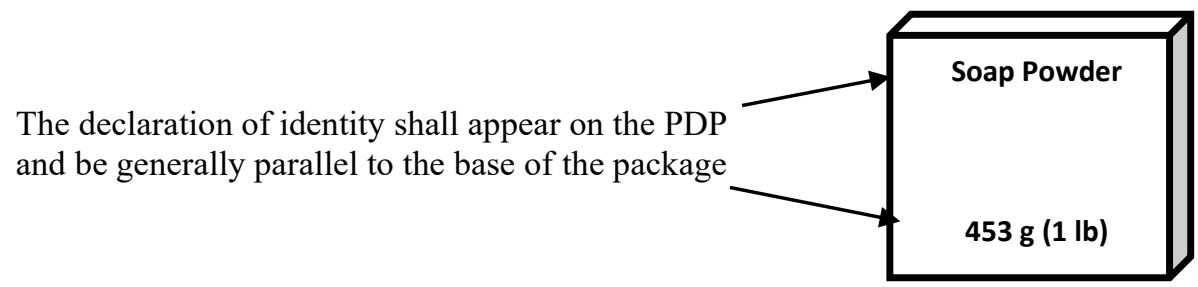

Figure 1. Declaration of Identity on a Principal Display Panel

\title{
Section 2. Declaration of Responsibility
}

A package kept, offered, or exposed for sale, or sold at any place other than on the premises where it is packaged shall conspicuously display the following information:

\section{a. Name of Responsible Party}

The name shall be the actual corporate name, or, when not incorporated, the name under which the business is conducted. When the product is not manufactured by the person or business whose name appears on the label, the name shall be qualified by a phrase that reveals the connection such person has with such commodity, such as "Manufactured for and packed by ," "Distributed by ," or any other wording of similar import that expresses the facts.

\section{b. Address of Responsible Party}

The address shall include street name or number, city, state (and country if outside the United States), and ZIP Code (or mail code used in other countries). However, the street address may be omitted if it is listed in a readily accessible, widely published, and publicly available resource, including but not limited to a printed directory, electronic database, or Web site. If a person manufactures, packs, or distributes a product or commodity at a location other than his principal place of business, the label may state the principal place of business or corporate headquarters in lieu of the actual place where the product or commodity was manufactured or packed or is to be distributed, unless that statement would be misleading.

\section{Examples of a Declaration of Responsibility:}

\author{
Glad Foods \\ 1600 Gateway Street \\ Waterloo, PA 18017 \\ Glad Foods \\ Waterloo, PA 18017 \\ Glad Foods \\ P. O. Box $1800(*)$ \\ Waterloo, PA 18017 \\ www.gladfoods.com $(*)$ \\ 1-800-326-1212 (*)
}

(*) Optional information may be added but the required information must be included.

It is not necessary to say, "manufactured by" when the name is that of the actual producer. When it is not, the name shall be accurately identified (i.e., "Distributed by," "Made for," "Imported by.") A Uniform Resource Locator (URL) for the company's Web site, a telephone number, or a Post Office box may be included, but these are not acceptable substitutes for the required street name and address information. 


\section{Section 3. Declaration of Net Quantity of Contents}

Only the actual quantity of product (excluding packaging and other tare material) in the package is declared in the net quantity statement. A net quantity declaration that does not permit price and quantity comparisons is prohibited.

\section{a. Units of Measure - Use of SI (Metric System) and U.S. Customary Units - Order of Presentation}

Units of the International System of Units (SI) (metric system) and U.S. Customary Units are acceptable for use in the quantity declaration. The declaration of quantity on most packages are subject to FTC and FDA regulations and shall include both SI and U.S. customary units. Packaged goods subject only to State regulation under the UPLR may be labeled with only SI units (metric) in the quantity declaration. When both SI and U.S. customary units appear on a package either unit of measurement may appear first (see Exemption 11.33 "U.S. Customary Units Consumer Commodities" in the UPLR).

Example: Units may be shown in either order: Net Weight $2 \mathrm{~kg}(4.4 \mathrm{lb})$ or Net Weight $4.4 \mathrm{lb}(2 \mathrm{~kg})$

\section{b. The Accuracy of Net Quantity Declarations and Package Requirements}

The net quantity of contents shall be an "accurate" declaration of the amount of the product in the package. The package fill requirements and the test procedures for verifying the net quantity of contents, determining tare weight and other packager requirements, as well as the value of the permitted reasonable variations from the labeled net quantity of contents are described in NIST Handbook 133 "Checking the Net Contents of Packaged Goods" at www.nist.gov/pml/weights-and-measures/publications/nist-handbooks/handbook-133.

\section{c. Location of Net Quantity Declaration}

The declaration of net quantity of contents shall appear in the lower $30 \%$ of the PDP and shall be in terms of the Largest Whole Unit (e.g., Net Wt $3 \mathrm{lb}$ not Net Wt $48 \mathrm{oz}$, and 1 gallon not 128 fluid ounces), unless otherwise specified in the UPLR. There are exemptions to the location of information in Part VII. "Exemptions from Labeling Requirements" (see Figure 2. "Location of the Declaration of Net Quantity of Contents").

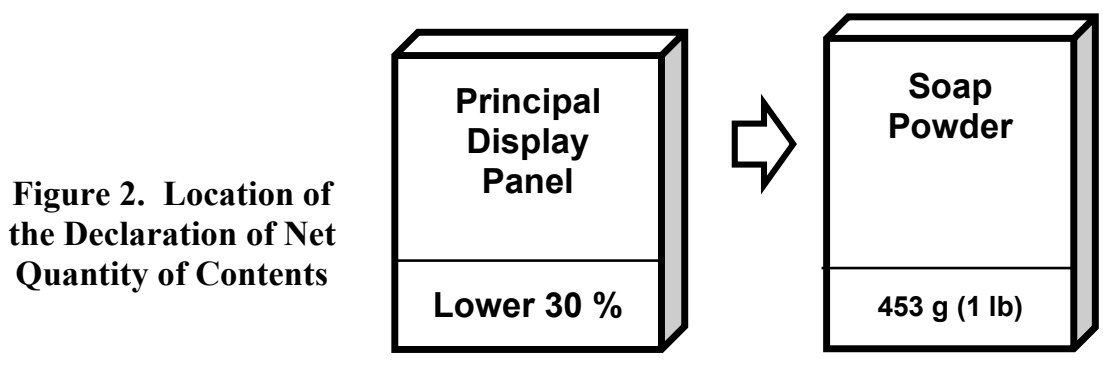

\section{d. Determine the Minimum Type Size Required for the Net Quantity of Contents Declaration}

It is not the size of a label affixed to package, but the entire surface area of the package that is shown to the customers that is used to determine type size. Calculate the area of the PDP and use the calculated area to select the minimum height of the numbers and letters from Table 1. "Minimum Height of Numbers and Letters."

\section{Calculate the Area of Principal Display Panel (PDP)}

The calculation is based on the shape of the package or label. Examples of two of the most common package shapes (e.g., rectangular and cylindrical) are shown below. 


\section{i. Rectangular Package}

For most packages the entire front panel displayed to consumers is considered the PDP. This area is calculated by multiplying the height (h) times the width $(\mathrm{w})($ Area $=h \times w)$.

Figure 3. PDP of a Rectangular Package.

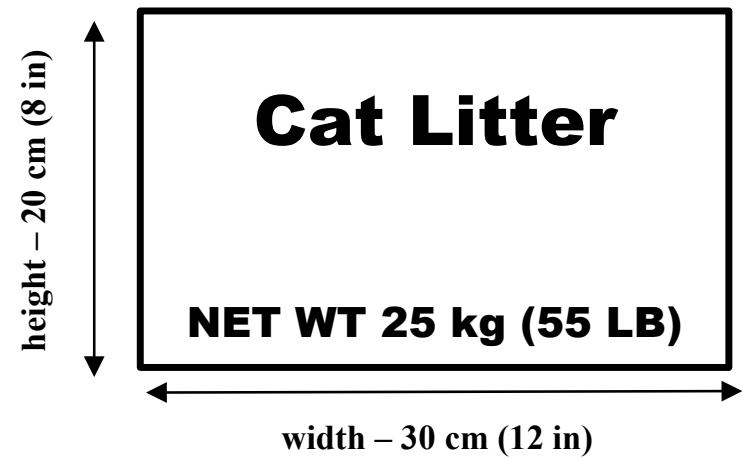

For this example, the height is 20 centimeters ( 8 inches) and the width is 30 centimeters (12 inches). Calculate the area of the PDP by multiplying $20 \times 30=$ Area of PDP is 600 square centimeters (or $8 \times 12=$ 96 square inches). For other geometric shapes (e.g., triangles, frustums, circles...) calculate the area using the appropriate geometric formula.

\section{ii. Cylindrical Package}

The area of the principal display panel for a cylindrical is calculated by multiplying the height (h) of the container by the circumference (c) times $40 \%($ Area $=(h \times c) \times 0.40)$. The circumference may be determined using a suitable flexible measure (e.g., diameter tape), or by multiplying the diameter by 3.14159 [Pi] (Circumference $=3.14159 \times$ Diameter $)$. see Figure 4. "Cylindrical Container."

Calculation: 25 centimeters $(10$ inches $) \times 5$ centimeters $(2$ inches $)=50$ square centimeters ( 8 square inches) $\times 0.40=$ PDP area is 20 square centimeters ( 3.2 square inches).



Figure 4. Cylindrical Container.

For bottles, cans and jars the area of the PDP is calculated using the height of the body of the container (the shoulder, neck, cap or heel (base) of a bottle or jar or the bottom flange of cans are not included in the container height) (see Figure 5. "Anatomy of a Bottle"). In Figure 5. "Anatomy of a Bottle" the body height of 150 millimeters (5.9 inches) is used to calculate the area of the PDP. 


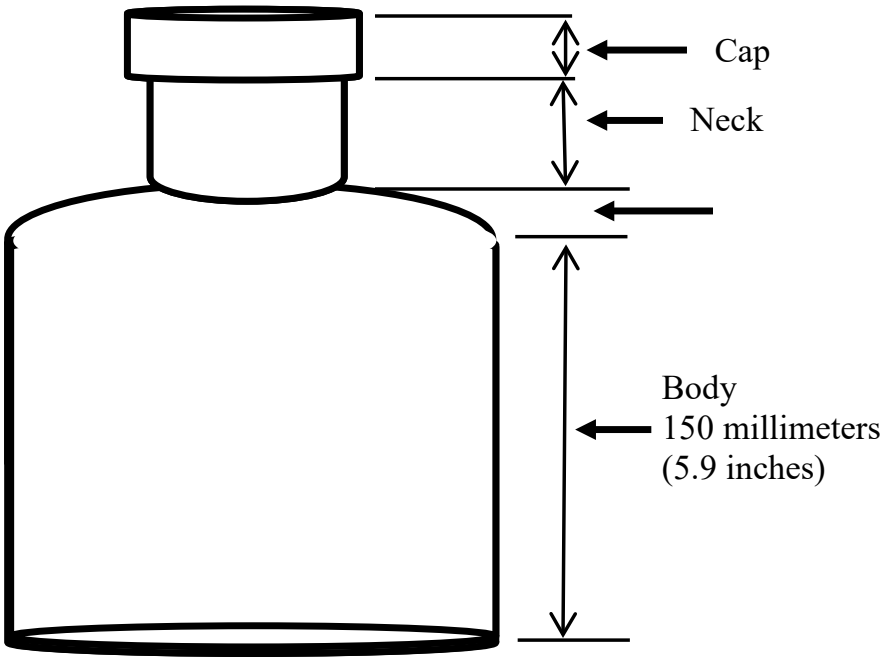

2. Select the Minimum Type Size of Numbers and Letters

i. Rectangular Example

To select the minimum type size for the example in Figure 3. "PDP of a Rectangular Package," find the area of the PDP (600 square centimeters [96 square inches]) in Table 1. "Minimum Height of Numbers and Letters." For this example, the minimum type size of 4.8 millimeters $(3 / 16 \mathrm{inch})$ is required.

\section{ii. Cylindrical Example}

To select the minimum type size for the example in Figure 4 "Cylindrical Container" find the area of the PDP (50 square centimeters [8 square inches]) in Table 1. "Minimum Height of Numbers and Letters." In this example, the minimum type size of 3.2 millimeters $(1 / 8$ inch) is required to be used.

\begin{tabular}{|c|c|c|c|c|c|}
\hline \multicolumn{6}{|c|}{$\begin{array}{l}\text { Table } 1 . \\
\text { Minimum Height of Numbers and Letters* }\end{array}$} \\
\hline \multicolumn{2}{|c|}{$\begin{array}{l}\text { Area of Principal Display } \\
\text { Panel }\end{array}$} & \multicolumn{2}{|c|}{$\begin{array}{l}\text { Minimum Height of Numbers } \\
\text { and Letters }\end{array}$} & \multicolumn{2}{|c|}{$\begin{array}{l}\text { Minimum Height of } \\
\text { Information Blown, Formed, } \\
\text { or Molded on Surface of } \\
\text { Container (e.g., plastic jug) }\end{array}$} \\
\hline $\begin{array}{c}\text { square } \\
\text { centimeters }\end{array}$ & square inches & millimeter & inch & millimeter & inch \\
\hline$\leq 32$ & $\leq 5$ & 1.6 & $1 / 16$ & 3.2 & $1 / 8$ \\
\hline$>32 \leq 161$ & $>5 \leq 25$ & 3.2 & $1 / 8$ & 4.8 & $3 / 16$ \\
\hline$>161 \leq 645$ & $>25 \leq 100$ & 4.8 & $3 / 16$ & 6.4 & $1 / 4$ \\
\hline$>645 \leq 2581$ & $>100 \leq 400$ & 6.4 & $1 / 4$ & 7.9 & $5 / 16$ \\
\hline$>2581$ & $>400$ & 12.7 & $1 / 2$ & 14.3 & $9 / 16$ \\
\hline
\end{tabular}




\section{Measuring the Type Size of Numbers and Letters}

The height of any letter or number in the quantity declaration shall be not less than that shown in Table 1. "Minimum Height of Numbers and Letters." As described in 4. "Style of Type or Lettering and Proportion" below, no number or letter shall be more than three times as high as it is wide.

The height and width of a number or letter is measured at its outermost edges as shown in Figure 6. "Measure the Height and Width of Numbers and Letters."

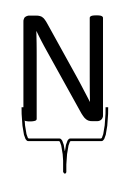
Figure 6. Measure the
Height and Width of
Numbers and Letters.

NOTES: The height of numbers of a common fraction shall be at least one-half the minimum height requirement. When upper and lowercase or all lowercase letters are used in U.S. customary units, it is the lowercase "o" or its equivalent that shall meet the minimum height requirement. When upper and lowercase or all lowercase letters are used in SI symbols, it is the uppercase "L," lowercase "d," or their equivalent in the print or type that shall meet the minimum height requirement. No letter or number shall be less than 1.6 millimeter $\left({ }^{1} / 16\right.$ inch) in height. Other letters and exponents shall be presented in the same type style and in proportion to the type size used. Any required label information blown, formed, or molded on surface of a container (e.g., plastic and glass milk jugs or bottles) must meet the height requirements specified in Table 1. "Minimum Height of Numbers and Letters."

\section{Style of Type or Lettering and Proportion}

The declaration(s) of quantity shall be in such a style of type or lettering as to be boldly, clearly, and conspicuously presented with respect to other type, lettering, or graphic material on the package. No number or letter in the quantity declaration shall be more than 3 times as high as it is wide (See Figure 7. "Proportion of Numbers and Letters" for an illustration). Measure the width and height of the number or letter as explained in 3. "Measuring the Type Size of Numbers and Letters."

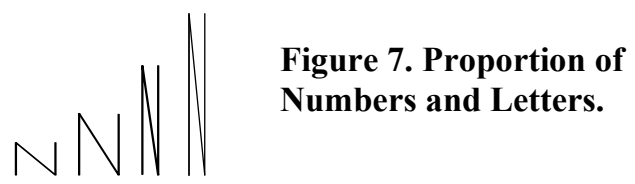

\section{Color Contrast}

The declaration(s) of quantity shall be shown in a color that contrasts conspicuously with its background. For example, the quantity declaration shown in white text in Figure 8 "Label with Poor Contrast" is nearly unreadable due to the poor contrast while the black text in Figure 9 "Label with Good Contrast" is clear and conspicuous.

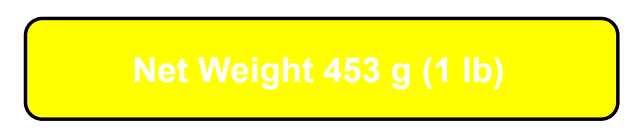

Net Weight $454 \mathrm{~g}(1 \mathrm{lb})$ 


\section{6. $\quad$ Free Area}

The area surrounding the quantity declaration shall be free of printed information above and below, by a space equal to at least the height of the lettering in the quantity declaration (e.g., typically this the height of the letter "N" used in the word net with the same font as the quantity declaration); and, to the left and right, by a space equal to twice the width of the letter " $\mathrm{N}$ " of the style and size of type used in the declaration.

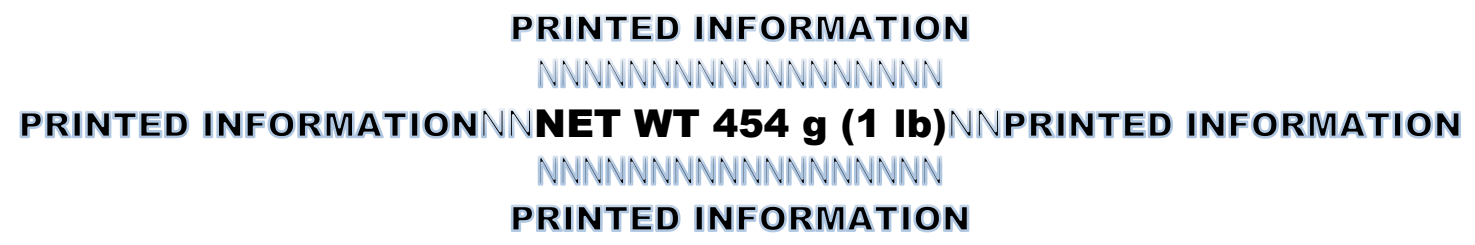

\section{Parallel Quantity Declaration}

The quantity declaration (and the product identity) shall be presented in such a manner as to be generally parallel to the declaration of identity and the base on which the package rests as it is designed to be displayed (See Figure 11. "Parallel Declarations of Identity and Quantity"). This applies to pre-printed labeling as well as to labels that are applied in supermarkets, delis and other stores (e.g., random weight packages). The declaration of quantity shall be in the lower $30 \%$ of PDP and be generally parallel to the base of the package.

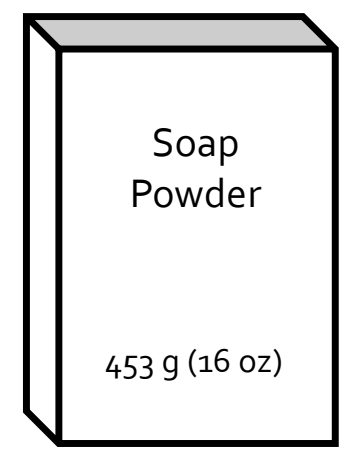

Acceptable

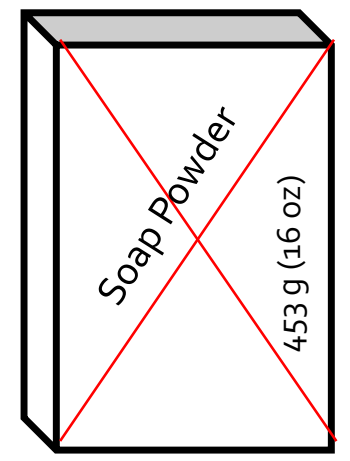

Not Acceptable

\section{Section 4. Largest Whole Unit}

The declaration of quantity shall be in terms of the largest whole unit with any remainder expressed in fractions.

Example: $3 \mathrm{lb}$ not $48 \mathrm{oz}$ or 1 gallon not 128 fluid ounces or $3 \mathrm{lb} 2 \mathrm{oz}$ not $50 \mathrm{oz}$

\section{a. SI Units}

Shall be shown in decimal fractions of largest whole unit. Use common fractions with the SI Units is prohibited.

Example: $1.25 \mathrm{~kg}$ not $1 \frac{1}{4} \mathrm{~kg}$

The quantity in SI units shall not be expressed in mixed units.

Example: $3.5 \mathrm{~kg}$ not $3 \mathrm{~kg} 500 \mathrm{~g}$ 


\section{b. U.S. Customary Units}

Units of the U.S. customary system shall be shown in common or decimal fractions of the largest whole unit; or the next smaller whole unit or units with any further remainder in terms of common or decimal fractions of the smallest unit used in the quantity declaration.

Example: $5 \mathrm{lb} 4 \mathrm{oz}$, or $3 \mathrm{lb} 2^{1 / 4} \mathrm{oz}$, or $4.25 \mathrm{lb}$

Equivalent units may be stated in the net quantity of contents if it is also shown in terms of the largest whole unit.

Example: $3 \mathrm{lb}(48 \mathrm{oz})$ or 1 Gallon $(128 \mathrm{fl} \mathrm{oz})$

\section{Section 5. Qualification of a Quantity Declaration is Prohibited}

In no case shall any declaration of quantity be qualified with the words "when packed," "minimum," or "not less than" or any words or symbols (e.g., \pm or $\sim$ ) of similar import (i.e., "approximately"), nor shall any unit of weight, measure, or count on a package be qualified by any term (such as "jumbo," "giant," "full,") or like term or symbol that may tend to exaggerate the quantity of the commodity.

\section{Section 6. Combination Declarations of Net Quantity of Contents}

When a quantity declaration of weight, measure or count is not fully informative on its own, it shall be combined with the appropriate additional declarations or weight, measure, or count. A combination of declarations of the net quantity of contents shall be accurate and shall appear on the principal display panel.

Example: Trash bags require count, dimensions, thickness, and capacity to be fully informative.

$$
200 \text { Count } 49.2 \mathrm{~L}(13 \mathrm{gal}) 60.9 \mathrm{~cm} \times 68.5 \mathrm{~cm}(2 \mathrm{ft} \times 2 \mathrm{ft} 3 \mathrm{in}) 22.8 \mu \mathrm{m}(0.90 \mathrm{mil})
$$

\section{Section 7. Supplementary Quantity Declarations}

The quantity declaration may be supplemented by one or more declarations of weight, measure, or count but these shall not appear on the Principal Display Panel (PDP). A supplemental statement may appear on the back, sides, or top of a package but shall not include any term qualifying a unit of weight, measure, or count that tends to exaggerate the amount of product or commodity in the package (e.g., may not include the terms "giant quart," "large liter," "full gallon," "when packed," "minimum," or similar words). The following is an example of an acceptable supplementary quantity declaration (it must appear on the back or side panel of the package not the PDP):

$$
\text { Evaporated Milk - } 430 \mathrm{~mL} \text { (back panel includes a quantity declaration of } 100 \mathrm{~g} \text { ) }
$$

The following are examples not supplementary quantity declarations, and they may appear on the PDP to supplement the required declaration of quantity:

- A declaration of ounces in addition to the largest whole unit (e.g., $1 \mathrm{lb}[16 \mathrm{oz}]$ ).

- A declaration of count (in addition to the required net weight declaration) on packages of hot dog or hamburger buns or packages of sliced cheese.

- A declaration of count (in addition to the net weight) on packages of sliced cheese or number of cups (a household measure) of cheese contained in a package of shredded product.

- The number of servings the package contains. 


\section{Section 8. Terms Permitted to be Shown with a Net Quantity Declaration}

A quantity declaration may stand alone (e.g., $200 \mathrm{~g} \mathrm{(7} \mathrm{oz)} \mathrm{or} 473 \mathrm{~mL}(16 \mathrm{fl} \mathrm{oz})$ ") or these terms can precede or follow the quantity declaration. The declaration may include the term "NET WEIGHT" (or NET by itself if used on a food label) if labeled by weight and may include the term NET or NET CONTENTS if labeled by volume or count.

\section{Section 9. $\quad$ Lines of Print or Type}

A declaration of quantity may appear on one or more lines of print or type as shown in Figure 12. "Information on One or More Lines."

\begin{tabular}{|c|c|c|}
\hline $\begin{array}{c}\text { Duct Tape } \\
5 \text { inches } \times 300 \text { yards } \\
(127 \mathrm{~mm} \times 274 \mathrm{~m})\end{array}$ & or & $\begin{array}{c}\text { Duct Tape } \\
5 \text { inches } \times \mathbf{3 0 0} \text { yards }(127 \mathrm{~mm} \times 274 \mathrm{~m})\end{array}$ \\
\hline
\end{tabular}

Figure 12. Information on One or More Lines.

\section{Section 10. Conversions and Rounding}

Conversions and rounding shall be based on the packer's knowledge of the accuracy of the original measurement and the effect of that accuracy on the quantity being converted. When expressing equivalent SI or U.S. customary unit quantities on a package, neither declaration is allowed to overstate the actual quantity. To avoid overstating the quantity it is permissible to round a converted quantity down. When, because of rounding, SI or U.S. customary units result in values that are not exact, inspectors will verify the largest declaration of net quantity (either SI or U.S. Customary). When rounding to show an equivalent SI or U.S. customary quantity, the number of significant digits retained shall be such that accuracy is neither sacrificed nor exaggerated. When making conversions it is important that the complete conversion factors be used in calculations, they should not be rounded before they are used. However, the result can be rounded after calculations are completed.

\section{Section 11. Symbols and Abbreviations}

\section{a. SI Units and Symbols}

The symbols in Table 2. "Acceptable SI Symbols for Use in a Quantity Declaration" shall be used in the quantity statement on a package:

\begin{tabular}{|c|c||c|c||}
\hline \multicolumn{4}{|c||}{ Table 2. } \\
Acceptable SI Symbols for Use in a Quantity Declaration \\
\hline \hline Unit & Symbol & Unit & Symbol \\
\hline centimeter & $\mathrm{cm}$ & cubic meter & $\mathrm{m}^{3}$ \\
\hline cubic centimeter & $\mathrm{cm}^{3}$ & kilogram & $\mathrm{kg}$ \\
\hline meter & $\mathrm{m}$ & gram & $\mathrm{g}$ \\
\hline milligram & $\mathrm{mg}$ & millimeter & $\mathrm{mm}$ \\
\hline Liter & $\mathrm{L}$ or $~$ & square meter & $\mathrm{m}^{2}$ \\
\hline milliliter & $\mathrm{mL} \mathrm{or} \mathrm{ml}$ & cubic decimeter & $\mathrm{dm}^{3}$ \\
\hline square centimeter & $\mathrm{cm}$ & square decimeter & $\mathrm{dm}^{2}$ \\
\hline micrometer & $\mu \mathrm{m}$ & microgram & $\mu \mathrm{g} \mathrm{or} \mathrm{mcg}^{2}$ \\
\hline
\end{tabular}


(1) These symbols except for the L for liter, shall not be capitalized unless the unit is derived from a proper name.

Examples: prohibited symbols include: Kg, K, G, GR, MG, ML.

(2) a. A period should not be placed after an SI symbol (e.g., $3 \mathrm{~m}$ or $10 \mathrm{~g}$ not $3 \mathrm{~m}$. or $10 \mathrm{~g}$.).

b. A comma should not be used in place of a decimal point in quantities (e.g., $10.0 \mathrm{~g}$ or $23.8 \mathrm{~mL}$ not $10,0 \mathrm{~g}$ or $23,8 \mathrm{~mL})$.

(3) Symbols shall always be written in the singular form. Do not add an "s" to an SI symbol.

Examples: prohibited symbols include gs or cms.

(4) Use of the "L" symbol and the " $\mathrm{mL}$ " symbol are preferred; however, the "l" symbol for liter and "ml" symbol for milliliter are permitted.

(5) A space should be used between the SI symbol and the unit to which it refers but the space is not mandatory.

Example: $250 \mathrm{~g}$ but not $250 \mathrm{~g}$

(6) The quantity shall not be expressed in mixed units.

Example: $3.5 \mathrm{~kg}$ but not $3 \mathrm{~kg} 500 \mathrm{~g}$

(7) Rule of 1000

The selected multiple or submultiple prefixes for SI units shall result in numerical values between 1 and 1000. This rule requires milligrams to be used when a weight declaration is less than $1 \mathrm{gram}$, and kilograms to be used when a weight declaration is 1000 grams or more.

Example: $500 \mathrm{mg}$ but not $0.5 \mathrm{~g} ; 1.4 \mathrm{~kg}$ but not $1400 \mathrm{~g}$

Note: the UPLR allows centimeter or millimeters to be used where a length declaration is less than 100 centimeters.

Example: $750 \mathrm{~mm}$ or $75 \mathrm{~cm}$, not $0.75 \mathrm{~m}$

\section{(8) Number of Digits Displayed}

SI declarations shall be shown in three digits except where the quantity is below 100 grams. If the quantity is less than 100 grams it may be shown in two digits. In either case, any final zero appearing to the right of the decimal point need not be shown.

Example: $454 \mathrm{~g}$ not $453.592 \mathrm{~g}$; $85 \mathrm{~g}$ or $85.1 \mathrm{~g}$, not $85.0 \mathrm{~g}$ or $101 \mathrm{mg}$ not $101.00 \mathrm{mg}$

\section{b. Abbreviations for U.S. Customary Units and Other Terms}

The abbreviations in Table 3. "Abbreviations for U.S. Customary Units and Other Terms" and no others may be used in place of the units or terms in the quantity statement on a package: 
Table 3.

Abbreviations for U.S. Customary Units and Other Terms

\begin{tabular}{|c|c||c|c||c|c||}
\hline \hline Unit or Term & Abbreviation & Unit or Term & Abbreviation & Unit or Term & Abbreviation \\
\hline avoirdupois & avdp & feet or foot & $\mathrm{ft}$ & $\mathrm{pint}$ & $\mathrm{pt}$ \\
\hline count & $\mathrm{ct}$ & fluid & $\mathrm{fl}$ & pound & $\mathrm{lb}$ \\
\hline cubic & $\mathrm{cu}$ & gallon & gal & quart & $\mathrm{qt}$ \\
\hline diameter & $\mathrm{dia}$ & inch & in & square & sq \\
\hline drained & $\mathrm{dr}$ & liquid & liq & weight & $\mathrm{wt}$ \\
\hline each & $\mathrm{ea}$ & ounce & $\mathrm{oz}$ & yard & $\mathrm{yd}$ \\
\hline fluid & $\mathrm{fl}$ & piece & $\mathrm{pc}$ & & \\
\hline
\end{tabular}

1. Do not include a period after an abbreviation. Write abbreviations in singular form; an "s" to express a plural should not be added. For example, "oz" is the abbreviation for both "ounce" and "ounces."

2. Both upper and lowercase letters are acceptable (e.g., Gal or GAL or gal) as long as the required minimum height requirements are met.

3. Prohibited symbols: Use of the crosshatch (\#) for the pound (e.g., 3\#) and the use of the quotation mark (") for inches (e.g., 4") or the quote mark (') for feet (e.g., 3').

4. Exponents are acceptable (e.g., $\mathrm{ft}^{2}$ for square feet or $\mathrm{cm}^{3}$ for cubic centimeters).

5. The quantity may be expressed in mixed units (e.g., pounds and ounces or feet and inches).

Examples: both $2.25 \mathrm{lb}$ or $2 \mathrm{lb} 4 \mathrm{oz}$ are acceptable.

\section{Section 12. Method of Sale}

Some commodities are required to be sold in specific methods of sale. See the "Uniform Regulation for the Method of Sale of Commodities" in NIST Handbook 130 for specific requirements. If there is not a specific requirement, Table 4. "Method of Sale Requirements" applies to most goods, products or commodities.

\begin{tabular}{||l|c|}
\hline \multicolumn{2}{|c|}{ Method of Sable Requirements } \\
\hline \hline If the commodity is: & Then the quantity shall be expressed as: \\
\hline $\begin{array}{l}\text { A solid, semisolid, viscous, or a mixture of } \\
\text { solid and liquid }\end{array}$ & weight or mass \\
\hline A liquid & fluid volume measure \\
\hline A dry commodity & dry measure \\
\hline Labeled by linear measure or area & linear measure or area \\
\hline Labeled by numerical units (count) & numerical count \\
\hline
\end{tabular}




\section{Section 13. Multi-Unit Packages}

Any package containing more than one individual package of a product shall bear on the outside of the package a declaration of the number of individual units; the quantity of each individual unit; and the total quantity of contents of the multi-unit package. The term "total" or the phrase "total contents" may precede the quantity declaration.

Example: 6 - Soap Bars

Net Wt 100 g (3.53 oz) Each

Total Net Weight: $600 \mathrm{~g}(1.32 \mathrm{lb})$

\section{a. Individual Packages Labeled for Individual Retail Sale in a Multi-Unit Package}

For foods, a multi-unit package is a package containing two or more individually packaged units of an identical commodity of the same quantity that are intended to be sold as part of the multi-unit package but are individually labeled in compliance with requirements (i.e., identity, net quantity, and declaration of responsibility) [see Figure 13. "Open (or transparent package) Multi-Unit Package"]. Open multi-unit retail food packages (e.g., the old style 6-pack carton of bottled beverages or boxes or fruit in transparent wrapping), that do not obscure the number of units or prevent examination of the labeling on each of the individual units are not required to declare the number of individual units or the total quantity of contents for the multi-unit package if each individual unit is labeled in full compliance with the requirements and capable of being sold alone.

Figure 13. Open (or transparent package) Multi-Unit Package

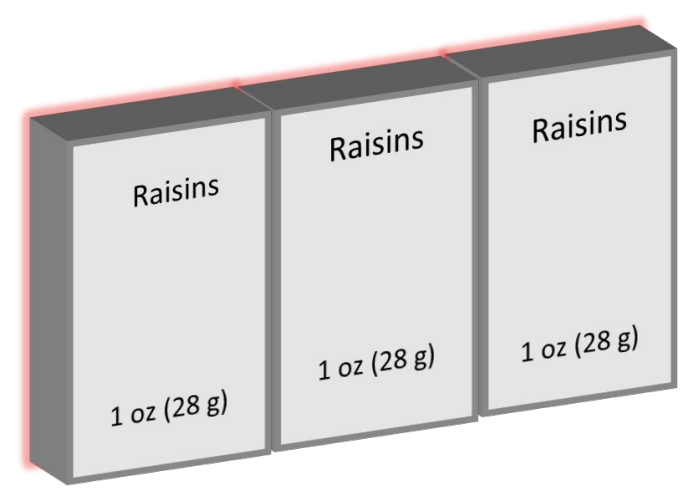

\section{b. Individual Packages Not Labeled for Individual Retail Sale in a Multi-Unit Package}

A multi-unit package containing unlabeled individual packages which are not labeled for retail sale separate from the multi-unit package may contain, in lieu of the requirements above, a declaration of quantity of contents expressing the total quantity of the multi-unit package without regard for inner packaging. For such multi-unit packages, it shall be optional to include a statement of the number of individual packages when such a statement is not otherwise required by the regulations.

Example: Deodorant Cakes

5 - Deodorant Cakes

Net Wt 113 g (4 oz) Each

Total Net Wt 566 g $(1.25 \mathrm{lb})$

or

5 - Deodorant Cakes

Total Net Wt 566 g (1 lb 4 oz) 


\section{Section 14. Combination Packages}

A combination package is one that contains two or more individual units of dissimilar commodities. The quantity declaration shall contain a declaration of weight, volume, measure, or count, or any combination of these, for each individual package or unit. However, the quantity statement of identical packages or units shall be combined.

Example: A picnic pack that contains utensils, napkins and cups might be labeled on the PDP with:

$$
\begin{aligned}
& 20-\text { Spoons } \\
& 10-\text { Knives } \\
& 10-\text { Forks } \\
& 10-25 \mathrm{~cm} \times 25 \mathrm{~cm}(10 \text { in } \times 10 \text { in }) 2 \text {-ply Napkins } \\
& 10-177 \mathrm{~mL} \text { ( } 6 \text { fluid ounce) Cups }
\end{aligned}
$$

\section{Section 15. Variety Packages}

A variety package is one that contains two or more individual units of similar, but not identical, commodities. Commodities are generically the same, but differ in weight, measure, volume, appearance, or quality are considered similar, but not identical. The quantity declaration shall contain a declaration of weight, volume, measure, count, size, or any combination of these, for each individual unit; and a declaration of weight, volume, measure, count size of any combination of these, for the total package.

\section{Example: Sponges}

$$
\begin{aligned}
& 4-15.2 \mathrm{~cm} \times 25.4 \mathrm{~cm} \times 2.5 \mathrm{~cm}(6 \text { in } \times 10 \text { in } \times 1 \text { in }) \\
& 4-10.1 \mathrm{~cm} \times 20.3 \mathrm{~cm} \times 1.9 \mathrm{~cm}(4 \mathrm{in} \times 8 \text { in } \times 3 / 4 \text { in }) \\
& \text { Total: } 8 \text { Sponges }
\end{aligned}
$$

The statement of total quantity shall appear as the last item in the declaration of net quantity and shall not be of greater prominence than the other terms used on the label. When the individual packages in a variety package are either packaged or labeled and are intended for retail sale as individual units, each package shall be labeled in compliance with the applicable sections of the UPLR and all other labeling requirements applicable to the product. 


\section{Part 3. $\quad$ Packages Labeled by Weight (mass)}

\section{Section 1. Packages Must be Sold by Net Weight}

The net quantity declaration must not include the weight of the container, wrappers, or packing material (called "tare weight"). In addition, the wax on cheese or ice glaze often applied on frozen foods is considered tare weight and shall not be included in the net weight. Selling packaged goods by "gross weight" is illegal.

A quantity declaration may stand alone [e.g., $200 \mathrm{~g} \mathrm{(7} \mathrm{oz)} \mathrm{or} 1 \mathrm{lb}(453 \mathrm{~g})$ ] or may include the term "net mass" or "net weight" either preceding or following the declaration. The term "net" by itself may be used on food labels. However, the quantity of contents shall always declare the net quantity of contents even when such terms as "Net Weight" or "Net Content" are not used. See Figure 14. "Package Labeled by Weight" for an example.

Example: $453 \mathrm{~g}(1 \mathrm{lb})$ or Net Wt $453 \mathrm{~g}(1 \mathrm{lb})$ or Net $453 \mathrm{~g}(1 \mathrm{lb})$

\section{Section 2. Unit Declarations by Weight}

\section{a. Units for SI (Metric) Declarations}

Use only the unit name or symbol in Table 5. "SI Units and Symbols" in a declaration of net quantity of contents by weight.

\begin{tabular}{|c|c|}
\hline \multicolumn{2}{|c|}{ Table 5. } \\
SI Units and Symbols and Other Terms and Abbreviations \\
\hline \hline The units of mass used in an SI quantity declaration shall be in terms of: \\
\hline Unit Name & Symbol \\
\hline kilogram & $\mathrm{kg}$ \\
\hline gram & $\mathrm{g}$ \\
\hline milligram & $\mathrm{mg}$ \\
\hline Term & Abbreviation \\
\hline net & No abbreviation \\
\hline weight & $\mathrm{wt}$ \\
\hline drained weight & $\mathrm{dr} w \mathrm{t}$ \\
\hline
\end{tabular}

\section{b. SI - Largest Whole Unit}

Use Table 6. "SI Units - Largest Whole Unit" to identify the largest whole unit to be used in the declaration of net quantity of contents.

\begin{tabular}{||l|l||}
\hline \multicolumn{2}{||c||}{ SI Units - Largest Whole Unit } \\
\hline \hline If the net weight is: & Then declare* the net weight in: \\
\hline Less than 1 gram & milligrams \\
\hline $\begin{array}{l}\text { 1 gram or more, but less } \\
\text { than 1 kilogram }\end{array}$ & $\begin{array}{l}\text { grams and decimal fractions of a gram (e.g., } 420.2 \mathrm{~g} \text { not } 420-1 / 5 \mathrm{~g} \text { ) and not } \\
\text { in mixed units (e.g., } 3.5 \mathrm{~g} \text { not } 3 \mathrm{~g} 500 \mathrm{mg})\end{array}$ \\
\hline
\end{tabular}


Table 6.

SI Units - Largest Whole Unit

1 kilogram or more

kilograms and decimal fractions of a kilogram (e.g., $1.25 \mathrm{~kg}$ not $1-1 / 4 \mathrm{~kg}$ )

and not in mixed units (e.g., $3.5 \mathrm{~kg}$ not $3 \mathrm{~kg} 500 \mathrm{~g}$ )

\section{c. Units for U.S. Customary Quantity Declarations}

Only the units and terms or abbreviations in Table 7. "U.S. Customary Units and Other Terms and Abbreviations" may be used in conjunction with a weight declaration.

\begin{tabular}{|c|c||}
\hline \multicolumn{2}{|c|}{ Table 7.} \\
U.S. Customary Units and Other Terms and Abbreviations \\
\hline \hline Unit or Term & Abbreviation \\
\hline pound & $\mathrm{lb}$ \\
\hline ounce & $\mathrm{oz}$ \\
\hline net & No abbreviation \\
\hline weight & $\mathrm{wt}$ \\
\hline drained weight & $\mathrm{dr} w t$ \\
\hline
\end{tabular}

\section{d. Largest Whole Unit}

Use Table 8. "U.S. Customary Units and Other Terms and Abbreviations" to identify the largest whole unit to be used in the declaration of net quantity of contents.

Table 8.

U.S. Customary Units and Other Terms and Abbreviations

\begin{tabular}{|l|l|}
\hline \hline If the net weight is: & Then declare* the net weight: \\
\hline Less than one pound & In ounces and fractions of an ounce \\
\hline One pound or more & $\begin{array}{l}\text { In pounds with any remainder expressed as either fractions of a pound, } \\
\text { or ounces and fractions of an ounce. }\end{array}$ \\
\hline Any remainder & $\begin{array}{l}\text { As a common or decimal fraction of pound or ounce (e.g., } 1.5 \mathrm{lb}, 3^{1 / 2} / \mathrm{lb}, \\
\left.14.3 \mathrm{oz}, \text { and } 12^{1 / 4} \mathrm{oz}\right) ; \text { or, may be expressed in the next smaller whole } \\
\text { unit with any reminder shown as a common or decimal fraction of the } \\
\left.\text { smaller unit (e.g., } 5 \mathrm{lb} 4 \mathrm{oz}, 1 \mathrm{lb} 7.5 \mathrm{oz} \text { and } 3 \mathrm{lb} 2^{1 / 4} \mathrm{oz}\right) .\end{array}$ \\
\hline
\end{tabular}




\section{Section 3. Factors for Converting Units of Weight}

Use Table 9. "Factors for Converting Units of Weight" to find the appropriate factor for use in converting U.S. Customary and SI units (metric units) to be used in the declaration of net quantity of contents.

\begin{tabular}{|c|c|c|c|c|c|}
\hline \multicolumn{6}{|c|}{$\begin{array}{c}\text { Table } 9 . \\
\text { Factors for Converting Units of Weight } \\
\quad \text { (underlined figures are exact) }\end{array}$} \\
\hline Unit & Pounds & Ounces & Milligrams & Grams & Kilograms \\
\hline 1 pound $=$ & 1 & $\underline{16}$ & $\underline{453592.37}$ & $\underline{453.59237}$ & $\underline{0.45359237}$ \\
\hline 1 ounce $=$ & $\underline{0.0625}$ & $\underline{1}$ & $\underline{28349.523125}$ & $\underline{28.349523 \quad 125}$ & $\underline{0.028349523 \quad 125}$ \\
\hline 1 milligram $=$ & 0.000002204623 & 0.00003527396 & $\underline{1}$ & $\underline{0.001}$ & $\underline{0.000001}$ \\
\hline 1 gram $=$ & 0.002204623 & 0.03527396 & $\underline{1000}$ & $\underline{1}$ & $\underline{0.001}$ \\
\hline 1 kilogram $=$ & 2.204623 & 35.27396 & $\underline{1000000}$ & $\underline{1000}$ & $\underline{1}$ \\
\hline
\end{tabular}

Example 1: You have a $4 \mathrm{lb}$ package and you want to determine the equivalent metric quantity to declare on the label. To convert pounds to kilograms, multiply pounds by the conversion factor 0.45359237 :

$$
4 \mathrm{lb} \times 0.45359237 \mathrm{~kg} / \mathrm{lb}=1.81436948 \mathrm{~kg}
$$

The metric quantity can be rounded or truncated (which means the extra digits are dropped but remaining digits are typically not rounded up to avoid overstating the quantity $-1.81436948 \mathrm{~kg}$ ). Since SI units must be shown in only 2 or 3 digits, the quantity declaration could be displayed as:

$$
4 \mathrm{lb}(1.81 \mathrm{~kg}) \text { or } 1.81 \mathrm{~kg}(4 \mathrm{lb}) \text { or } 4 \mathrm{lb}(1.8 \mathrm{~kg}) \text { or } 1.8 \mathrm{~kg}(4 \mathrm{lb})
$$

Example 2: You have an 8 oz package and want to determine the equivalent metric quantity declare on the label. To convert ounces to grams, multiply grams by the conversion factor 28.349523125 :

$$
8 \mathrm{oz} \times 28.349523125 \mathrm{~g} / \mathrm{oz}=226.796185 \mathrm{~g}
$$

The metric quantity can be rounded or truncated (the extra digits are dropped but remaining digits are typically not rounded up to avoid overstating the quantity -226.796185). Since SI metric units are shown in only 2 or 3 digits, the quantity declaration should be:

$$
8 \mathrm{oz}(226 \mathrm{~g}) \text { or } 226 \mathrm{~g}(8 \mathrm{oz})
$$

Notes: If 226.796185 is rounded up to $227 \mathrm{~g}$, and assuming the packer's target fill weight is $8 \mathrm{oz}$, the packages will be underweight. This is because inspectors verify the largest of the two quantities (i.e., $8 \mathrm{oz}$ and $227 \mathrm{~g}$ ) \{which in this case would be the metric units\}. Also, to ensure weighing accuracy, inspectors use scales with an accuracy of $0.1 \mathrm{~g}$ or better to verify the net quantity of contents of packaged goods. 


\section{SUMMARY OF PACKAGE REQUIREMENTS (WEIGHT)}

\section{Declaration of Identity}

- Appears on PDP and is generally parallel to the base of the package.

- Includes a common or usual name or other appropriate description.

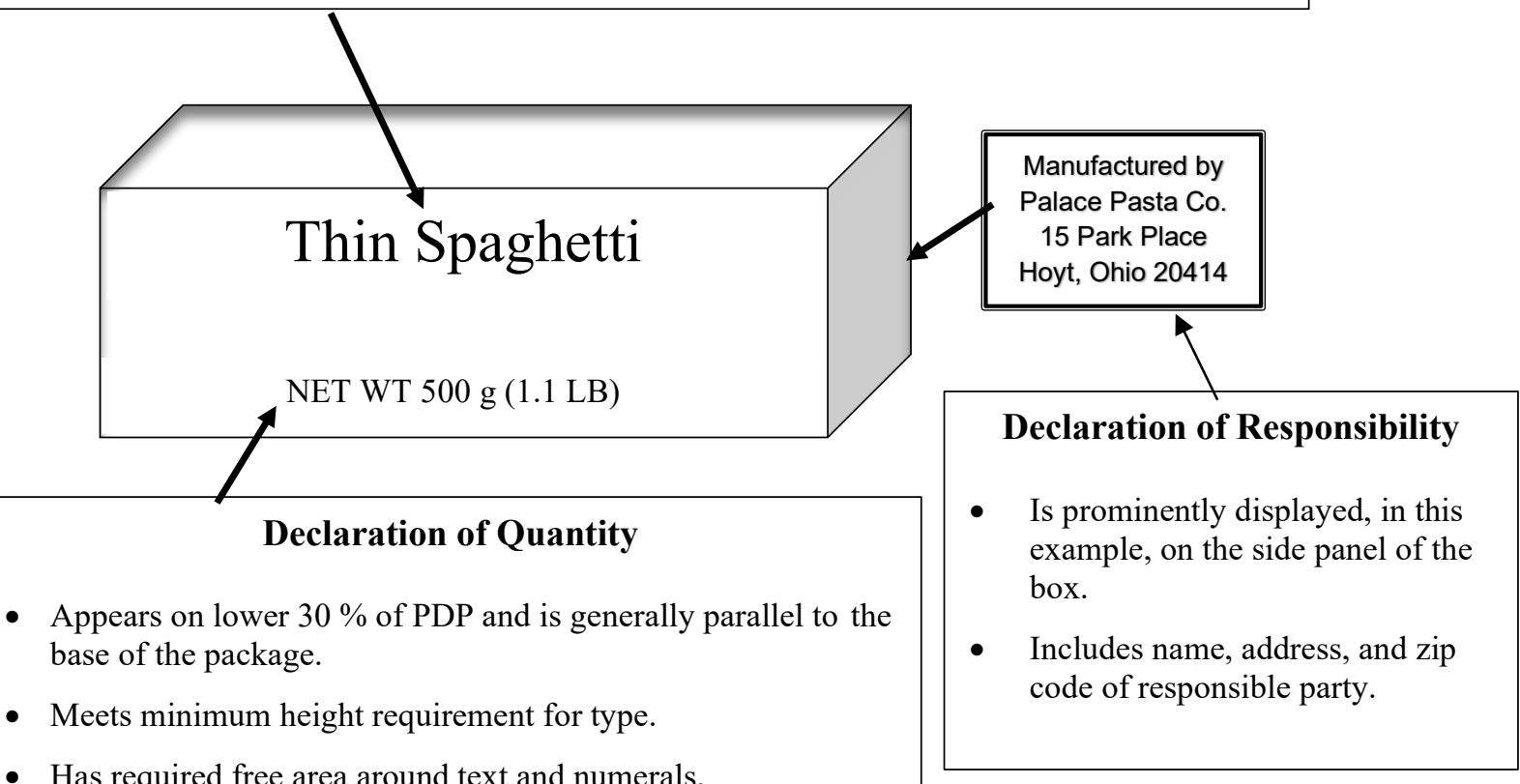

- Has proper color contrast.

- Uses correct symbols for SI units and abbreviations for U.S. Customary Units. 


\section{Part 4. Packages Labeled by Volume}

\section{Section 1. Words Accompanying a Quantity Declaration}

A quantity declaration may stand alone or may include the term "net" or "net contents" either preceding or following the declaration.

Examples: $473 \mathrm{~mL}$ (1 PT) or Net $473 \mathrm{~mL}$ (1 PINT); or Net Contents 1.89 L (2 QT)

\section{Section 2. $\quad$ Product Reference Temperatures}

All declarations of quantity associated with a liquid measure shall express the volume at the specified reference temperature as shown in the Table 10. "Reference Temperatures for Products Sold by Fluid Measure."

\begin{tabular}{|l|c|}
\hline \multicolumn{2}{|c|}{ Table 10. } \\
\hline \multicolumn{1}{|c|}{ Reference Temperatures for Products Sold by Fluid Measure } \\
\hline \hline \multicolumn{1}{|c|}{ If the product is: } & Then the Reference Temperature is: \\
\hline Distilled Spirits & $15.6^{\circ} \mathrm{C}\left(60{ }^{\circ} \mathrm{F}\right)$ \\
\hline Frozen Food & At the frozen temperature \\
\hline Beer (Malt) & $4{ }^{\circ} \mathrm{C}\left(39.1^{\circ} \mathrm{F}\right)$ \\
\hline Petroleum & $15.6^{\circ} \mathrm{C}\left(60^{\circ} \mathrm{F}\right)$ \\
\hline $\begin{array}{l}\text { Refrigerated food (e.g., dairy products labeled "Keep } \\
\text { Refrigerated") }\end{array}$ & $4{ }^{\circ} \mathrm{C}\left(40^{\circ} \mathrm{F}\right)$ \\
\hline $\begin{array}{l}\text { Other liquids and wine (e.g., includes liquids sold in a } \\
\text { refrigerated state for immediate consumption such as soft } \\
\text { drinks, bottled water and others that do not require } \\
\text { refrigeration. }\end{array}$ & $20^{\circ} \mathrm{C}\left(68^{\circ} \mathrm{F}\right)$ \\
\hline
\end{tabular}

\section{Section 3. Units for SI (metric) Declarations}

The SI units of liquid and dry measure used to declare the net contents in an SI quantity declaration shall be in as shown in Table 11. "Units and Symbols for SI Units":

\begin{tabular}{|c|c|}
\hline \multicolumn{2}{|c|}{ Table 11. } \\
\hline \hline \multicolumn{2}{|c|}{ Units and Symbols for SI Units } \\
\hline For Liquid or Dry Volume: & Symbol \\
\hline liter & L or 1 \\
\hline milliliter & $\mathrm{mL}$ or $\mathrm{ml}$ \\
\hline For Cubic Measure: & $\mathrm{m}^{3}$ or cu m \\
\hline cubic meter & $\mathrm{dm}^{3}$ or cu dm \\
\hline cubic decimeter* & $\mathrm{cm}^{3}$ or cu cm \\
\hline cubic centimeter & \\
\hline
\end{tabular}


*Some products are sold by dry volume such as soil, mulch, firewood, and animal bedding which are required to have their quantities labeled by liters or milliliters

not cubic decimeters

\section{Section 4. Requirements for Quantity Declarations in U.S. Customary Units}

Only the following units, terms and abbreviations in Table 12. "U.S. Customary Units and Other Terms and Abbreviations" may be used in conjunction with a volume declaration. The units of liquid, dry, and cubic measure shall be used in terms of: Fluid, Dry, and Cubic Measure.

\begin{tabular}{|c|c|}
\hline \multicolumn{2}{|c|}{ Table 12. } \\
\hline U.S. Customary Units and Other Terms and Abbreviations \\
\hline Unit & Abbreviation \\
\hline bushel & none \\
\hline cubic foot & $\mathrm{ft}^{3}$ or cu ft \\
\hline cubic inch & $\mathrm{in}^{3}$ or cu in \\
\hline cubic yard & $\mathrm{yd}^{3}$ or cu yd \\
\hline dry pint & dry pt \\
\hline dry quart & dry qt \\
\hline fluid ounce & fl oz \\
\hline gallon & gal \\
\hline liquid & liq \\
\hline peck & none \\
\hline pint & pt \\
\hline quart & qt \\
\hline
\end{tabular}

\section{Section 5. $\quad$ Largest Whole Unit}

Use Table 13. "U.S. Customary Units - Largest Whole Unit" to determine the largest whole unit and other requirement to be used in the declaration of net quantity of contents.

\begin{tabular}{||l|l||}
\hline \multicolumn{2}{|c|}{ U.S. Customary Units - Largest Whole Unit } \\
\hline \hline If the declaration of quantity is: & Then the declaration of quantity shall: \\
\hline In terms of dry measure. & Include the term "dry" (e.g., "1 Dry Quart") \\
\hline A liquid volume of less than one pint. & Be expressed in fluid ounces and fractions of a fluid ounce. \\
\hline
\end{tabular}


Table 13.

U.S. Customary Units - Largest Whole Unit

\begin{tabular}{|c|c|}
\hline If the declaration of quantity is: & Then the declaration of quantity shall: \\
\hline \multirow{2}{*}{$\begin{array}{l}\text { A liquid volume of at least one pint, but less } \\
\text { than one gallon. }\end{array}$} & $\begin{array}{l}\text { Be expressed in terms of the largest whole unit (quarts, quarts } \\
\text { and pints, or pints) with any remainder expressed in fluid } \\
\text { ounces or fractions of the pint or quart. }\end{array}$ \\
\hline & $\begin{array}{l}\text { An exception is that two quarts may be declared as one-half } \\
\text { gallon. }\end{array}$ \\
\hline A liquid volume of more than one gallon. & $\begin{array}{l}\text { Be expressed in terms of the largest whole unit (gallons, } \\
\text { gallons and quarts, or gallons and pints). With any } \\
\text { remainder expressed in fluid ounces or fractions of the pint } \\
\text { or quart. This declaration may be accompanied by an } \\
\text { additional declaration in fluid ounces. }\end{array}$ \\
\hline A dry volume of one dry pint or more. & $\begin{array}{l}\text { Be expressed in terms of the largest whole unit (dry pint, } \\
\text { dry quart, peck, or bushel) with any remainder expressed in } \\
\text { fractions of the smallest unit. }\end{array}$ \\
\hline \multirow{2}{*}{ Any remainder. } & $\begin{array}{l}\text { Be expressed as either a common or decimal fraction (e.g., } \\
\text { " } 1.5 \text {-gal," " } 31 / 2 \text { qt," " } 14.3 \mathrm{fl} \mathrm{oz",} \mathrm{and} \mathrm{"} 12^{1 / 4} \mathrm{yd}^{3} \text { " are } \\
\text { acceptable). }\end{array}$ \\
\hline & $\begin{array}{l}\text { Be expressed in the next smaller whole unit or units with } \\
\text { any further reminder expressed in terms of a common or } \\
\text { decimal fraction of the smallest unit present (e.g., "1 gal } 1 \\
\text { pint" and " } 3 \mathrm{qt} 8.3 \mathrm{fl} \mathrm{oz"} \mathrm{are} \mathrm{acceptable).}\end{array}$ \\
\hline
\end{tabular}

\section{Section 6. Conversion Factors for Liquid Volume}

Use Table 14. "Factors for Converting Liquid Volume" to find the appropriate factor for use in converting U.S. Customary and SI units (metric) to be used in the declaration of net quantity of contents.

\begin{tabular}{||l|r|r|r|r|r||}
\hline \multicolumn{7}{|c|}{ Table 14. Factors for Converting Liquid Volume } \\
(underlined figures are exact)
\end{tabular}




\begin{tabular}{||l|c|c|}
\hline \multicolumn{3}{|c|}{ Table 14. Factors for Converting Liquid Volume } \\
(underlined figures are exact)
\end{tabular}

Example for Liquid Volume: You have a two-gallon package and want to determine the equivalent metric value to declare on the label. To convert gallons to liters multiply as follows using the conversion factor from the table which is shown as 3.785412 Liters:

$$
2 \mathrm{gal} \times 3.785412 \mathrm{~L} / \mathrm{gal}=7.570824 \mathrm{~L}
$$

The metric value can be truncated (the extra digits are dropped but remaining digits are not rounded up to avoid overstating the quantity $-7.570824 \mathrm{~L}$ ) to three digits. Since the SI units should be shown to two or three digits either of the following quantity declarations are acceptable:

$$
2 \text { Gallons (7.57 L) or 7.57 L (2 Gallons) }
$$

\section{Section 7. Factors for Converting the Volume of Dry Measure}

Use Table 15. "Factors for Converting the Volume of Dry Measures or Volume of Cubic Measures" to find the appropriate factor to convert U.S. Customary and SI units (metric) for use in the declaration of net quantity of contents.

\begin{tabular}{|l|r|r|r|r|r|r||}
\hline \multicolumn{7}{|c||}{ Table 15. Factors for Converting the Volume of Dry Measure } \\
underlined figures are exact)
\end{tabular}


Table 15. Factors for Converting the Volume of Dry Measure

(underlined figures are exact)

\begin{tabular}{|l|r|r|r|r|r|}
\hline \hline 1 cubic centimeter $=$ & 0.06102374 & 0.00003531467 & 0.000001307951 & $\underline{1}$ & $\underline{0.001}$ \\
1 cubic decimeter $=$ & 61.02374 & 0.03531467 & 0.001307951 & $\underline{1000}$ & $\underline{1}$ \\
1 cubic meter $=$ & 61023.74 & 35.31467 & 1.307951 & $\underline{1000000}$ & $\underline{1000}$ \\
\hline
\end{tabular}

Example for Dry Volume: You have a 5-dry quart package and want to determine the equivalent metric value to declare on the label. To convert dry quarts to liters multiply as follows using the conversion factor from the table which is shown as 1.101221 liters:

$$
5 \text { dry qt } \times 1.101221 \mathrm{~L} / \text { dry qt }=5.506105 \mathrm{~L}
$$

The metric value may be truncated (the extra digits are dropped but remaining digits are not rounded up to avoid overstating the quantity $-5.506105 \mathrm{~L}$ ) to 3 digits. Since the SI units should be shown to 2 or 3 digits either of the following quantity declarations are acceptable:

$$
\text { 5 Dry Quarts (5.5 L) or 5.5 L (5 Dry Quarts) }
$$

Example for Cubic Volume: You have a 3-Cubic Foot package and want to determine the equivalent metric value to declare on the label. To convert cubic feet to liters multiply as follows using the conversion factor for cubic feet to liters from the table which is shown as 28.316846592 Liters:

$$
3 \mathrm{cu} \mathrm{ft} \times 28.316846592 \mathrm{~L} / \mathrm{cu} \mathrm{ft}=84.9505359 \mathrm{~L}
$$

The metric value may be truncated (the extra digits are dropped but remaining digits are not rounded to avoid overstating the quantity -84.9505359 L) to 3 digits. Since the SI units should be shown to 2 or 3 digits the following quantity declarations are acceptable:

3 Cubic Feet (84.9 L) or 84.9 L (3 Cubic Feet)

NOTE: If the converted value of $84.9505359 \mathrm{~L}$ is rounded up to $85 \mathrm{~L}$ the package control process should ensure that the packages contains at least $85 \mathrm{~L}$ as the accuracy of the measurement procedure used by weights and measures officials can determine dry volumes accurately to $0.1 \mathrm{~L}$ or less. Shown below is an example of a package of container of liquid floor polish with the required label information identified.

\section{A Package Labeled by Fluid Volume}

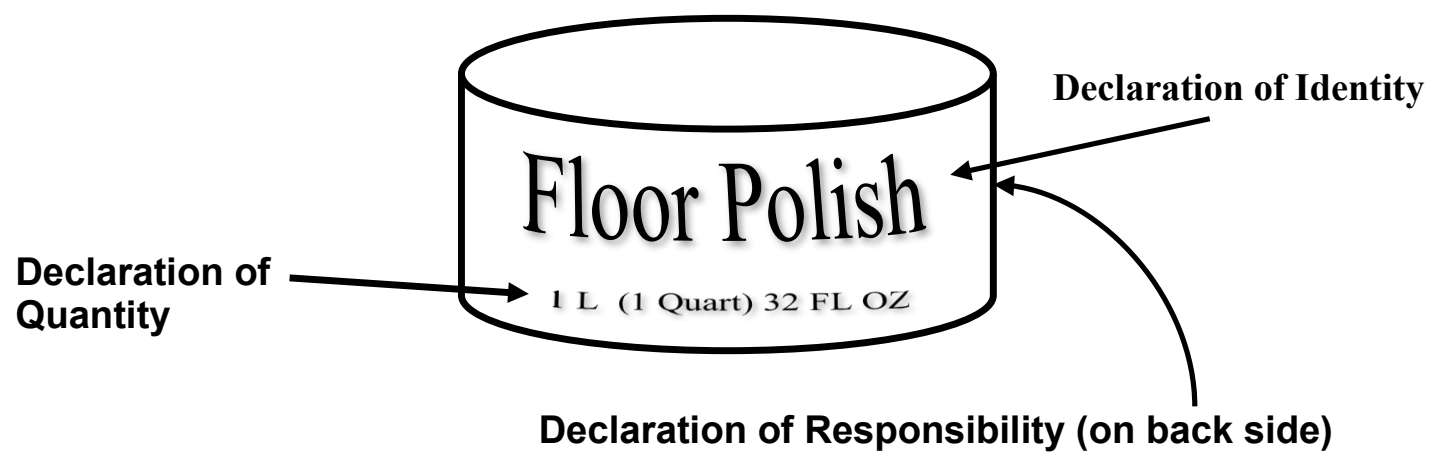




\section{Part 5. Packages Labeled by Measure (Length, Area, Thickness)}

\section{Section 1. Declaration of Quantity - Terms}

A quantity declaration must appear on the principal display panel of the package and may stand alone or may include the term "net" or "net quantity." Thickness measurements are required on products such as polyethylene sheeting and bags and other product and these requirements are described in the Uniform Method of Sale of Commodities Regulation in NIST Handbook 130.

Example: Net Qty $100 \mathrm{sq} \mathrm{cm}(3.28 \mathrm{sq} \mathrm{ft})$ or Net $15.24 \mathrm{~cm}(6 \mathrm{in})$

\section{Section 2. Declaration of Units}

\section{a. Units for SI (Metric System) Quantity Declarations}

Only the words and symbols in Table 16. "SI Units and Symbols" may be used in conjunction with a width or area declaration.

\begin{tabular}{|c|c|}
\hline \multicolumn{2}{|c|}{ Table 16. } \\
SI Units and Symbols \\
\hline \hline Unit & Symbol \\
\hline micrometer & $\mu \mathrm{m}$ \\
\hline millimeter & $\mathrm{mm}$ \\
\hline centimeter & $\mathrm{cm}$ \\
\hline meter & $\mathrm{m}$ \\
\hline square millimeter & $\mathrm{mm}^{2}$ or sq mm \\
\hline square centimeter & $\mathrm{cm}^{2}$ or sq cm \\
\hline square meter & $\mathrm{m}^{2}$ or sq m \\
\hline
\end{tabular}

\section{b. Largest Whole Unit}

The quantity declaration shall be in terms of the largest whole unit of length or area with any remainder expressed in decimal fractions to not more than three decimal places. Use Table 17. "SI Units - Largest Whole Unit Length or Area" to determine the largest whole unit to be used in the quantity declaration.

Table 17.

SI Units - Largest Whole Unit - Length or Area

\begin{tabular}{||l|l|}
\hline \hline If length is: & Then the quantity shall be expressed in: \\
\hline Less than one centimeter. & Millimeters. \\
\hline $\begin{array}{l}\text { More than one centimeter but less than } \\
\text { one meter. }\end{array}$ & $\begin{array}{l}\text { Centimeters (if less than } 100 \text { centimeters either centimeters or } \\
\text { millimeters may be used) }\end{array}$ \\
\hline More than one meter. & Meters \\
\hline & Then the quantity shall be expressed in: \\
\hline If area is: & Square millimeters. \\
\hline Less than one square centimeter &
\end{tabular}




\begin{tabular}{||l|l||}
\hline \multicolumn{2}{|c||}{ Table 17. } \\
\multicolumn{2}{|c||}{ SI Units - Largest Whole Unit - Length or Area } \\
\hline \hline Up to one square meter & Square centimeters. \\
\hline More than one square meter & Square meters. \\
\hline
\end{tabular}

\section{c. Units for U.S. Customary Units Declarations}

Only the words and abbreviations in Table 18. "U.S. Customary Units and Abbreviations" may be used in conjunction with a length or area declaration:

\begin{tabular}{|c|c|}
\hline \multicolumn{2}{|c|}{$\begin{array}{l}\text { Table } 18 . \\
\text { U.S. Customary Units and Abbreviations }\end{array}$} \\
\hline Unit & Abbreviation \\
\hline mil* & mil \\
\hline inch & in \\
\hline foot & $\mathrm{ft}$ \\
\hline yard & $\mathrm{yd}$ \\
\hline square inch & in $^{2}$ or sq in \\
\hline square foot & $\mathrm{ft}^{2}$ or sq $\mathrm{ft}$ \\
\hline square yard & $\mathrm{yd}^{2}$ or sq yd \\
\hline \multicolumn{2}{|c|}{$\begin{array}{l}\text { *A unit of length equal to one thousandth of an inch }(0.001) \text { or } \\
0.0254 \mathrm{~mm} \text {. Typically used in declaring the thickness of } \\
\text { polyethylene sheeting and bags or the diameter of wire. }\end{array}$} \\
\hline
\end{tabular}

\section{d. Largest Whole Unit}

Use Table 19. "U.S. Customary Units - Largest Whole Unit" to determine the largest whole unit and other requirement to be used in the declaration of net quantity of contents.

\begin{tabular}{||l|l||}
\hline \multicolumn{2}{||}{ U.S. Customary Units - Largest Whole Unit - Length or Area } \\
\hline \hline If length is: & Then the quantity* shall be expressed in: \\
\hline Less than one foot. & Inches and fractions of an inch. \\
\hline More than one foot, but less than one yard. & Feet and in fractions of a foot or in inches. \\
\hline More than one yard. & Yards and fractions of a yard. \\
\hline & Then the quantity* shall be expressed in: \\
\hline If area is: & Square inches and fractions of a square inch. \\
\hline Less than one square foot. & $\begin{array}{l}\text { Square feet and fractions of a square foot, or in square feet } \\
\text { with the remainder in square inches and fractions of a square } \\
\text { inch. }\end{array}$ \\
\hline One square foot to one square yard. & $\begin{array}{l}\text { Square yards and fractions of a square yard, or in square yards } \\
\text { and the remainder in square feet and square inches. }\end{array}$ \\
\hline More than one square yard &
\end{tabular}


*Any remainder may be expressed as either a common or decimal fraction (e.g., $1.5 \mathrm{yd}, 3^{1 / 2} \mathrm{ft}, 14.3 \mathrm{in}^{2}$, and $12 \frac{1}{4}$ sq yd are acceptable).

\section{Section 3. Factors for Converting Quantities of Length and Area}

To find the appropriate factor for use in converting U.S. Customary and SI units (metric) to be used in the declaration of net quantity of contents use Table 20. "Factors for Converting Length" and Table 21. "Factors for Converting Area."

\begin{tabular}{|c|c|c|c|c|c|c|}
\hline \multicolumn{7}{|c|}{$\begin{array}{l}\text { Table 20. Factors for Converting Length } \\
\text { (underlined figures are exact) }\end{array}$} \\
\hline Units & Inches & Feet & Yards & Millimeters & Centimeters & Meters \\
\hline 1 inch $=$ & $\underline{1}$ & 0.08333333 & 0.02777778 & 25.4 & 2.54 & 0.0254 \\
\hline 1 foot $=$ & $\underline{12}$ & $\underline{1}$ & 0.3333333 & $\underline{304.8}$ & $\underline{30.48}$ & $\underline{0.3048}$ \\
\hline 1 yard $=$ & $\underline{36}$ & $\underline{3}$ & 1 & 914.4 & 91.44 & $\underline{0.9144}$ \\
\hline 1 millimeter $=$ & 0.03937008 & 0.003280840 & 0.001093613 & $\underline{1}$ & $\underline{0.1}$ & $\underline{0.001}$ \\
\hline 1 centimeter $=$ & 0.3937008 & 0.03280840 & 0.01093613 & $\underline{10}$ & $\underline{1}$ & $\underline{0.01}$ \\
\hline 1 meter $=$ & 39.37008 & 3.280840 & 1.093613 & $\underline{1000}$ & $\underline{100}$ & 1 \\
\hline $1 \mathrm{mil}=$ & $\underline{0.001}$ & N/A & N/A & $\underline{0.0254}$ & 0.00254 & N/A \\
\hline \multicolumn{7}{|c|}{ Table 21. Factors for Converting - Area } \\
\hline Units & $\begin{array}{l}\text { Square } \\
\text { Inches }\end{array}$ & Square Feet & Square Yards & $\begin{array}{c}\text { Square } \\
\text { Millimeters }\end{array}$ & $\begin{array}{c}\text { Square } \\
\text { Centimeters }\end{array}$ & $\begin{array}{l}\text { Square } \\
\text { Meters }\end{array}$ \\
\hline $1 \mathrm{sq}$ inch $=$ & $\underline{1}$ & 0.006944444 & 0.0007716049 & 645.46 & 6.4516 & $\underline{0.00064516}$ \\
\hline $1 \mathrm{sq}$ foot $=$ & $\underline{144}$ & $\underline{1}$ & 0.1111111 & 7741.92 & $\underline{929.0304}$ & $\underline{0.09290304}$ \\
\hline 1 sq yard $=$ & $\underline{1296}$ & 9 & $\underline{1}$ & 836127.36 & $\underline{8361.2736}$ & $\underline{0.83612736}$ \\
\hline 1 sq millimeter $=$ & 0.00155 & N/A & N/A & $\underline{1}$ & $\underline{0.01}$ & $\underline{0.0000001}$ \\
\hline 1 sq centimeter $=$ & 0.1550003 & 0.001076391 & 0.0001195990 & $\underline{100}$ & $\underline{1}$ & $\underline{0.0001}$ \\
\hline 1 sq meter $=$ & 1550.003 & 10.76391 & 1.195990 & 1000000 & 10000 & $\underline{1}$ \\
\hline
\end{tabular}

For example: You have a product that is 100 feet long and you want to determine the equivalent metric value to declare on the label. To convert feet to meters, multiply the number of feet by the conversion factor from the table which is shown as 0.3048 :

$$
100 \mathrm{ft} \times 0.3048 \mathrm{~m} / \mathrm{ft}=30.48 \text { meters }
$$

The metric value may be truncated (the extra digits are dropped but remaining digits are not rounded up to avoid overstating the quantity -30.48 to 3 digits. Since the SI metric units should be shown to two or three digits the following quantity declarations are acceptable:

$100 \mathrm{ft}(30.4 \mathrm{~m})$ or $30.4 \mathrm{~m}(100 \mathrm{ft})$ 
For example: You have a product that is 50 square yards and you want to determine the equivalent metric value to declare on the label. To convert square yards to square meters, multiply the number of square yards by the conversion factor from the table which is shown as 0.83612736 :

$$
50 \mathrm{yd}^{2} \times 0.83612736 \mathrm{~m}^{2} / \mathrm{yd}^{2}=41.806368 \text { square meters }
$$

The metric value may be truncated (the extra digits are dropped but remaining digits are not rounded up to avoid overstating the quantity -41.806368$)$ to 3 digits. Since the SI metric units should be shown to two or three digits the following quantity declarations are acceptable:

50 sq yd (41.8 sq m) or 41.8 sq m (50 sq yd)

\section{An example of a package labeled by Weight, Count, Linear Measure and Thickness}






\section{Part 6. Packages Labeled by Count}

\section{Section 1. Quantity Declaration}

A quantity declaration of numerical count shall appear on the principal display panel of packages offered for sale on the basis of count. The quantity declaration can stand alone and should not include the terms "net quantity" or word "net." See Table 22. "Terms and Abbreviations for Declarations of Quantity by Count" for acceptable terms and abbreviations for use on packages labeled by numerical count.

\begin{tabular}{|c|c|}
\hline \multicolumn{2}{|c|}{ Table 22. } \\
Terms and Abbreviations for Declarations of Quantity by Count \\
\hline \hline Term & Abbreviation \\
\hline count & ct \\
\hline each & ea \\
\hline piece & pc \\
\hline
\end{tabular}

Examples: 12 pieces or 500 count or 12 pc or $500 \mathrm{ct}$

\section{Section 2. Labeling Packages by Count}

When a packaged consumer commodity is measured in terms of count only, or in terms of count and some other appropriate unit (e.g., length, width, thickness or diameter), such packages shall be labeled in full accord with the UPLR, including a statement of count. See Figure 17. "Package Labeled by Count, Linear Measure and Diameter" for an example of a box of glue sticks with the required label information. When the net contents declaration of a package includes count, the FPLA (e.g., items under the FDA or FTC regulations) provides no exemption from declaring the count unless the package only contains a single item. Packages with only a single unit are not required to declare the quantity of "one (1)" provided the statement of identity clearly conveys the fact that only one item is in the package (e.g., "light bulb"). If, however, the packaged food or consumer commodity is not under FDA or FTC regulations and the individual units are fully visible to the purchaser, a statement of count is not required if the package contains six or less units. Depending on the commodity, net quantity statements specifying weight, volume, length, or area are required in addition to count if count alone is not fully informative. See the Method of Sale of Commodities Regulation in NIST Handbook 130 for more information.

\section{Figure 17. A Package Labeled by Count, Linear Measure and Diameter}

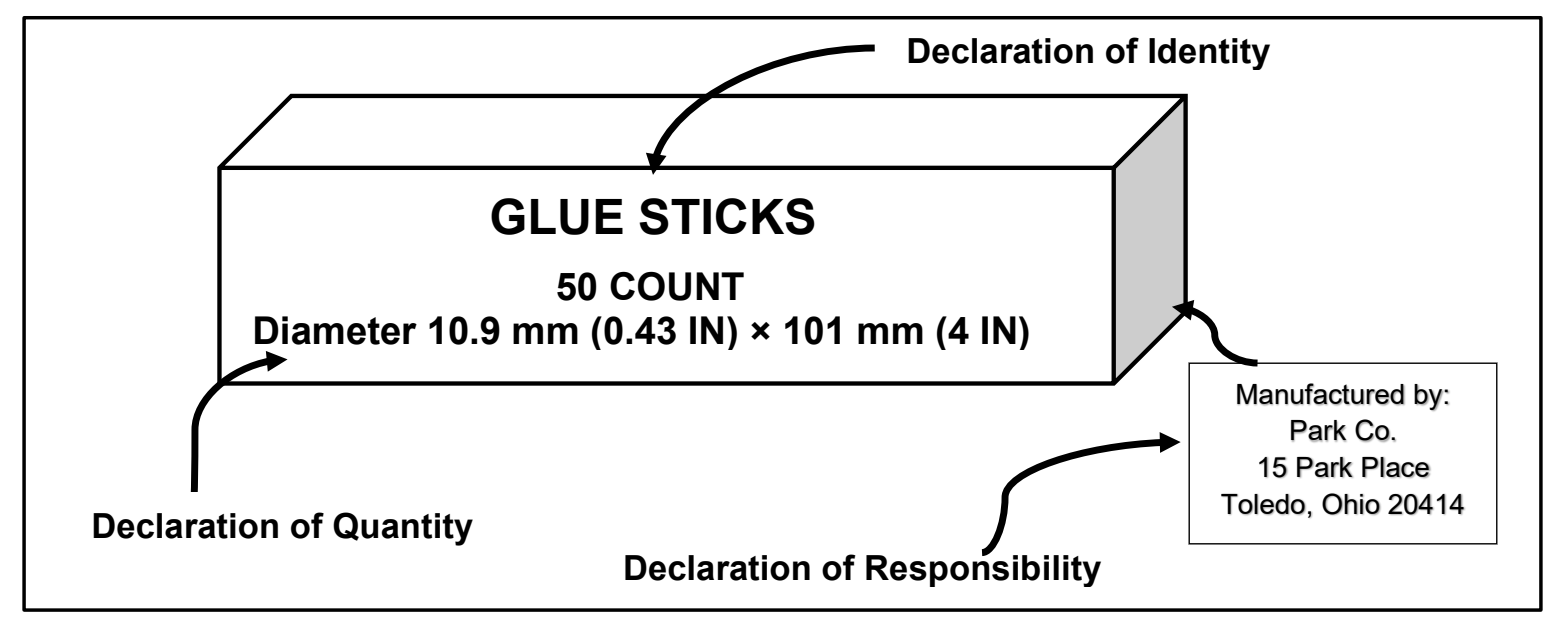




\section{Part 7. Exemptions to Labeling Requirements}

There are a wide variety of sizes and types of packages in the marketplace there are several exemptions to the declaration of identity and quantity labeling requirements for some packages. Table 23. "Exemptions to Labeling Requirements" provides an alphabetical list of the exemptions for individual products and the corresponding UPLR Section where the full text can be found. See Section 11. "Exemptions" in the UPLR at: www.nist.gov/pml/wmd/pubs/hb130.cfm.

\begin{tabular}{|c|c|}
\hline \multicolumn{2}{|c|}{$\begin{array}{l}\text { Table } 23 . \\
\text { Exemptions to Labeling Requirements }\end{array}$} \\
\hline Product & UPLR Section \\
\hline Butter & 11.13. Butter \\
\hline $\begin{array}{l}\text { Candy - Small Confections (individually wrapped } \\
\text { "penny candy" that weigh less than } 15 \mathrm{~g}[1 / 2 \mathrm{oz}] \text { ) }\end{array}$ & 11.2. Small Connections \\
\hline Cigarettes and Small Cigars & 11.7. Cigarettes and Small Cigars \\
\hline Combination Packages & 11.18. Combination and Variety Packages \\
\hline $\begin{array}{l}\text { Condiment Packets - Individual Serving Packets } \\
\text { (e.g., small packets of artificial sweeteners or sugar) }\end{array}$ & 11.4. Individual Servings \\
\hline Corn Flour and Corn Meal & 11.20. Corn Flour and Corn Meal \\
\hline Cosmetics - Decorative Containers of Cosmetics & 11.17. Decorative Containers \\
\hline Count - Packaged Commodities Sold by Count & 11.27. Packaged Commodities Sold by Count \\
\hline Eggs & 11.14. Eggs \\
\hline $\begin{array}{l}\text { Film - Camera Film, Video Recording Tape, Audio } \\
\text { Recording Tape, and Other Image and Audio } \\
\text { Recording Media }\end{array}$ & $\begin{array}{l}\text { 11.22. Camera Film, Video Recording Tape, Audio } \\
\text { Recording Tape, and Other Image and Audio Recording } \\
\text { Media }\end{array}$ \\
\hline Flour & 11.15. Flour \\
\hline $\begin{array}{l}\text { Fluid Dairy Products, Ice Cream, and Similar Frozen } \\
\text { Desserts }\end{array}$ & $\begin{array}{l}\text { 11.9. Fluid Dairy Products, Ice Cream, and Similar } \\
\text { Frozen Desserts }\end{array}$ \\
\hline $\begin{array}{l}\text { Header Strip - a label that is attached across the top } \\
\text { of a transparent or opaque bag or other container that } \\
\text { bears no other printed or graphic material. }\end{array}$ & 11.30. Header Strip \\
\hline Margarine & 11.19. Margarine \\
\hline $\begin{array}{l}\text { Meat Snacks - Small Packages of Meat or Meat } \\
\text { Products (individually wrapped pieces that weigh } \\
\text { less than } 15 \mathrm{~g}(1 / 2 \mathrm{oz}))\end{array}$ & 11.3. Small Packages of Meat or Meat Products \\
\hline Motor Oil in Cans & 11.24. Motor Oil in Cans \\
\hline $\begin{array}{l}\text { Reusable (Returnable) Glass Containers (e.g., soda } \\
\text { bottles) (See also } 11.12 \text { below) }\end{array}$ & 11.6. Reusable (Returnable) Glass Containers \\
\hline
\end{tabular}




\begin{tabular}{|c|c|}
\hline \multicolumn{2}{|c|}{$\begin{array}{c}\text { Table } 23 . \\
\text { Exemptions to Labeling Requirements }\end{array}$} \\
\hline Product & UPLR Section \\
\hline $\begin{array}{l}\text { Packaged Commodities with Labeling Requirements } \\
\text { Specified in Federal Law - (e.g., Treasury for } \\
\text { tobacco, alcohol, and beer; USDA Food Safety and } \\
\text { Inspection Service for meat, catfish, and poultry; EPA } \\
\text { for pesticides; FDA - food, cosmetics and drugs; FTC } \\
\text { for non-food consumer commodities). }\end{array}$ & $\begin{array}{l}\text { 11.8. Packaged Commodities with Labeling Requirements } \\
\text { Specified in Federal Laws and Regulations. } \\
\text { Reference information can be found in HB 130, UPLR, } \\
\text { Appendix C. }\end{array}$ \\
\hline Prescription and Insulin Containing Drugs & 11.21. Prescription and Insulin Containing Drugs \\
\hline $\begin{array}{l}\text { Pillows, Cushions, Comforters, Mattress Pads, } \\
\text { Sleeping Bags, and Similar Products }\end{array}$ & $\begin{array}{l}\text { 11.25. Pillows, Cushions, Comforters, Mattress Pads, } \\
\text { Sleeping Bags, and Similar Products }\end{array}$ \\
\hline $\begin{array}{l}\text { Random Weight Packages (e.g., meat, poultry, } \\
\text { seafood, cheeses, and produce sold in retail stores) }\end{array}$ & 11.1. Random Packages. \\
\hline SI Units, Exemptions - Consumer Commodities & 11.32. SI Units, Exemptions - Consumer Commodities. \\
\hline $\begin{array}{l}\text { Single Strength and Less than Single-Strength Fruit } \\
\text { Juice Beverages, Imitations thereof, and Drinking } \\
\text { Water }\end{array}$ & $\begin{array}{l}\text { 11.10. Single Strength \& Less than Single-Strength Fruit } \\
\text { Juice Beverages }\end{array}$ \\
\hline Small Packages & 11.16. Small Packages \\
\hline Soft Drink Bottles & 11.11. Soft Drink Bottles \\
\hline Soft Drink - Multi-Unit Soft Drink Packages & 11.12. Multi-unit Soft Drink Packages \\
\hline Spot Label & 11.29. Spot Label \\
\hline Textile Packages & 11.28. Textile Packages \\
\hline Tint Base Paint & 11.23. Tint Base Paint \\
\hline Cuts, Plugs, and Twists of Tobacco and Cigars & 11.5. Cuts, Plugs, and Twists of Tobacco and Cigars \\
\hline $\begin{array}{l}\text { U.S. Customary Units, Exemptions - Consumer } \\
\text { Commodities }\end{array}$ & $\begin{array}{l}\text { 11.33. U.S. Customary Units, Exemptions - Consumer } \\
\text { Commodities }\end{array}$ \\
\hline Variable Weight and Size Packages & 11.26. Commodities - Variable Weights and Sizes \\
\hline Variety Packages & 11.18. Combination and Variety Packages \\
\hline Wallpaper - Decorative Wallcovering Borders & 11.31. Decorative Wallcovering Borders \\
\hline
\end{tabular}




\section{Part 8. Label Review Checklist}

\section{Section 1. Declaration of Identity}

Appears on the principal display panel and is generally parallel to the base of the package.

Is the name specified in, or required by, federal or state regulation; the common or usual name; or the generic name or other appropriate description including a statement of function (e.g., polishing paste).

\section{Section 2. Declaration of Responsibility}

Is displayed on packages kept, offered, or exposed for sale or sold at a location other than where packed.

Includes the name and address of the manufacturer, the packer, or the distributor.

Uses the actual corporate name or, when not incorporated, the name under which the business is conducted.

Includes the city, state (or country), and ZIP code (or mailing code used in other countries).

Includes the street address unless this information is listed in a readily accessible, widely published, and publicly available resource, including but not limited to a printed directory, electronic database, or Web site.

Uses the address of the responsible party's principal place of business or the address of the location where the package was manufactured, packed, or distributed unless such address would be misleading.

If the responsible party is not the manufacturer, then includes the party's connection with the package (i.e., "Manufactured for and packed by," or "Distributed by").

\section{Section 3. Declaration of Quantity}

Appears in the lower $30 \%$ of the principal display panel and is generally parallel to the base of the package.

Is prominently displayed in English (multi-lingual information is permitted).

Is in a color that contrasts conspicuously with its background and has the required amount of free area.

Appears in a style of type or lettering is bold, clear, and conspicuous and the type or lettering is proportional.

Type or lettering meets the minimum height requirements.

Generally, includes both SI Units and U.S. Customary Units.

Uses only approved words, symbols or abbreviations for the SI and customary units in the singular form.

Uses SI symbols that are not capitalized and SI symbols and customary unit abbreviations are not accompanied by periods or with other punctuation marks.

Is declared in terms of the largest whole unit and SI units comply with the Rule of 1000. Quantities are rounded appropriately so quantity declarations are not overstated.

Uses SI declarations that are displayed in 2 or 3 digits and SI declarations contain only decimal fractions.

Does not appear in conjunction with an improper qualifying phrase.

When necessary, is combined with appropriate additional quantity declarations. 


\section{Part 9. Resources}

\begin{tabular}{|c|c|}
\hline \multicolumn{2}{|c|}{ RESOURCES } \\
\hline $\begin{array}{l}\text { National Institute of Standards and } \\
\text { Technology (NIST) } \\
\text { Office of Weights and Measures (OWM) } \\
\text { 100 Bureau Drive, Mailstop } 2600 \\
\text { Gaithersburg, MD 20899-2600 } \\
\text { Telephone: (301) 975-4004 } \\
\text { E-mail: owm@nist.gov }\end{array}$ & $\begin{array}{l}\text { Metric system: } \\
\text { E-mail: TheSI@nist.gov or visit www.nist.gov/metric } \\
\text { NIST Handbook } 130 \text { - "Uniform Laws and Regulations in } \\
\text { the Areas of Legal Metrology and Fuel Quality": } \\
\text { www.nist.gov/pml/weights-and- } \\
\text { measures/publications/nist-handbooks/handbook-130 } \\
\text { NIST Handbook } 133 \text { - "Checking the Net Contents of } \\
\text { Packaged Goods": www.nist.gov/pml/weights-and- } \\
\text { measures/handbook-133-2020-current-version }\end{array}$ \\
\hline $\begin{array}{l}\text { U.S. Federal Trade Commission (FTC) } \\
600 \text { Pennsylvania Ave, NW } \\
\text { Washington, DC } 20580 \\
\text { Telephone: (202) 326-2222 } \\
\text { www.ftc.gov }\end{array}$ & $\begin{array}{l}\text { The Fair Packaging and Labeling Act (FPLA) is available at: } \\
\text { www.ftc.gov/enforcement/statutes/fair-packaging-and- } \\
\text { labeling-act }\end{array}$ \\
\hline $\begin{array}{l}\text { U.S. Food and Drug Administration (FDA) } \\
5600 \text { Fishers Lane } \\
\text { Rockville, MD } 20857 \\
\text { Telephone: (888) } 463-6332 \\
\text { www.fda.gov }\end{array}$ & $\begin{array}{l}\text { "Guidance for Industry: Food Labeling Guide": } \\
\text { www.fda.gov/Food/GuidanceRegulation/GuidanceDocum } \\
\text { entsRegulatoryInformation/LabelingNutrition/ucm } 20068 \\
\text { 28.htm } \\
\text { Cosmetic Labeling Regulations search for Title 21, Chapter } \\
\text { I, Subchapter G, Part } 701 \text { "Cosmetic Labeling" at } \\
\text { www.ecfr.gov }\end{array}$ \\
\hline $\begin{array}{l}\text { U.S. Department of Agriculture (USDA) } \\
\text { Food Safety and Inspection Service (FSIS) } \\
1400 \text { Independence Ave., S.W. } \\
\text { Washington, DC } 20250-3700 \\
\text { Telephone: (301) 504-0868 } \\
\text { www.fsis.usda.gov }\end{array}$ & $\begin{array}{l}\text { For an overview of the USDA labeling requirements for } \\
\text { meat and poultry products see: } \\
\text { www.fsis.usda.gov/shared/PDF/Labeling_Requirements_ } \\
\text { Guide.pdf } \\
\text { Other labeling information: } \\
\text { www.fsis.usda.gov/wps/portal/fsis/topics/regulatory- } \\
\text { compliance/compliance-guides-index/labeling-guidance }\end{array}$ \\
\hline $\begin{array}{l}\text { U.S. Environmental Protection Agency (EPA) } \\
1200 \text { Pennsylvania Avenue, N.W. } \\
\text { Washington, DC } 20460 \\
\text { (202) 564-4700 } \\
\text { www.epa.gov }\end{array}$ & $\begin{array}{l}\text { For labeling requirements for pesticides: } \\
\text { Refer to } \$ \mathbf{1 5 6 . 1 0} \text { "Labeling requirements." } \\
\text { "Pesticide Registration - Label Review Manual" at } \\
\text { www.epa.gov/pesticide-registration/label-review-manual. }\end{array}$ \\
\hline
\end{tabular}




\section{Index}

\begin{abstract}
Abbreviations
Count .19

SI (metric system) ....................................... 9, 16

U.S. Customary Units and Other Terms .3, 8, 9, 10,



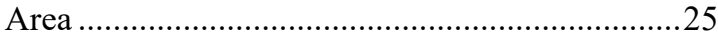

Dry Measure ......................................................21

Length.......................................................... 25

Liquid Measure..................................................20

Thickness.............................................................25

Weight (mass) ............................................... 14

\section{Count}

Packages sold by ....................................... 18, 23

Customary Units ............................................3, 8

Declaration of Product Identity

Location............................................................ 1

Parallel Display ............................................ 7

Product Identity ................................................. 1

Declaration of Quantity

Accuracy Requirements....................................... 3

Area .......................................................... 3

Combination Declarations ................................... 8

Conversions and Rounding................................. 9

Count ............................................. 18, 23, 27

Free Area ............................................................... 7

Largest Whole Unit ................. 3, 7, 14, 15, 19, 23

Length.............................................................. 23

Lines of Print or Type.......................................... 9

Location..................................................... 1

Method of Sale .................................................. 11

Minimum Type Size .................................... 3, 5

Net Weight ................................................... 7

Order of Presentation............................................. 3

Parallel Quantity, Display.................................... 7

Prohibited Qualifications ..................................... 9

Reference Temperatures for Fluid Products ........ 18
Rounding See Rounding SI Units (metric system) ......................... 9, 14, 18 Style of Type or Lettering and Proportion..............6 Supplementary Quantity Declarations ...................8 Thickness ............................................. 18, 23

Units of Measure ................................................ 3

Weight (mass) ................................................ 14

Declaration of Responsibility

Address of Responsible Party...............................2

Name of Responsible Party ..................................2

Exemptions to Labeling Requirements.................27

Importer .............. See Declaration of Responsibility

Introduction .....................................................................1 1

Labeling

General .......................................................... 1

Identity ......................................................... 1

Net quantity ................................................... 1

Quantity ........................................................... 3

Responsibility ................................................. 1, 2

Largest Whole Unit .See Rule of 1000, See Number of Digits Displayed

U.S. Customary Units .................................. 14, 19

Length

Packages sold by...

Manufacturer ...... See Declaration of Responsibility

Measuring the Type Size of Numbers and Letters6

Method of Sale ........................................................11

Minimum Type Size of Numbers and Letters ........5

Multi-Unit Packages ................................................12

Net Weight

Use of Terms ................................ 9, See Accuracy

Net, Net Contents

Use of Terms .................................................... 9

Package requirements .............................................3

Packages

Consumer.

Packer or Packager ...................... See Declaration of Responsibilty

Parallel, Display of Quantity and Product Identity ..............................................................................7

Principal Display Panel ..........See c. Location of Net Quantity Declaration

Area ..................................................................... 3

Bottles, Part of bottles included in PDP ................4

Calculation of Area.......................................... 4

Cylindrical Package............................................ 4

Rectangular Packages ..................................... 3, 4

Principle display panel ...............................................5

Product Identity ..........................................................1

Quantity............... See Declaration of Responsibility 
Quantity declarations ......................................1, 3

Resources................................................................31

Responsible PartySee Declaration of Responsibility

Rounding ...........................................................9, 11

Supplementary Quantity Declarations ..................8

Table of Contents.................................................... iii

Temperatures, Reference ........................................18

Thickness, Packages sold by ...........................18, 23

Type or Lettering Requirements

Color Contrast .................................................6

Color Proportion ................................................. 6

Free Area ........................................................ 7

Measuring ..................................................... 6
Minimum Height ........................................... 5

Parallel, Quantity and Identity.............................. 7

Style of Type or Lettering Proportions ..................6

Units of Measure

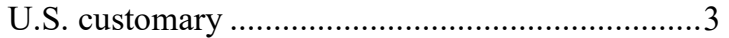

Variety Packages....................................................13

Volume

Packages sold by Fluid or Dry measure .............20

Weight

Net .................................................................... 14

Packages Sold by Weight (mass)........................ 14

Width

Packages sold by.

18,23 